\title{
THE STORM-GODS OF THE ANCIENT NEAR EAST: SUMMARY, SYNTHESIS, RECENT STUDIES
}

PART II

\author{
DANIEL SCHWEMER
}

\section{Abstract}

In many regions of the ancient Near East, not least in Upper Mesopotamia, Syria and Anatolia where agriculture relied mainly on rainfall, storm-gods ranked among the most prominent gods in the local panthea or were even regarded as divine kings, ruling over the gods and bestowing kingship on the human ruler. While the Babylonian and Assyrian storm-god never held the highest position among the gods, he too belongs to the group of 'great gods' through most periods of Mesopotamian history. Given the many cultural contacts and the longevity of traditions in the ancient Near East only a study that takes into account all relevant periods, regions and text-groups can further our understanding of the different ancient Near Eastern storm-gods. The study Wettergottgestalten Mesopotamiens und Nordsyriens by the present author (2001) tried to tackle the problems involved, basing itself primarily on the textual record and excluding the genuinely Anatolian storm-gods from the study. Given the lack of handbooks, concordances and thesauri in our field, the book is necessarily heavily burdened with materials collected for the first time. Despite comprehensive indices, the long lists and footnotes as well as the lack of an overall synthesis make the study not easily accessible, especially outside the German-speaking community. In 2003 Alberto Green published a comprehensive monograph entitled The Storm-God in the Ancient Near East whose aims are more ambitious than those of Wettergottgestalten: All regions of the ancient Near East - including a chapter on Yahwe as a storm-god-are taken into account, and both textual and iconographic sources are given equal space. Unfortunately this book, which was apparently finished and submitted to the publisher before Wettergottgestalten came to its author's attention, suffers from some serious flaws with regard to methodology, philology and the interpretation of texts and images. In presenting the following succinct overview I take the opportunity to make up for the missing synthesis in Wettergottgestalten and to provide some additions and corrections where necessary. It is hoped that this synthesis can also serve as a response to the history of ancient Near Eastern storm-gods as outlined by A. Green.

Part I (see $7 A N E R$ 7/2)

1. 'Storm-God': Scope and Limits of a Modern and Ancient Concept

2. Natural Phenomenon and Divine Manifestation

3. Sumerian Iškur 
3.1 Name and Early History

3.2 Development of the Cult in the Third Millennium

3.3 Deities Associated with Iškur

3.4 Modus Operandi in Religious Literature

4. Semitic Hadda

4.1 Name and Early History

4.2 Assyro-Babylonian Adad (Addu)

4.2.1 Third and Early Second Millennium

4.2.2 The First Half of the Second Millennium

4.2.3 The Second Half of the Second Millennium and the First Millennium

4.2.4 Adad in the God-Lists, the Circle of Deities Associated with Adad

4.2.5 The Goddess Šāla

4.2.6 Adad as God of Divination

4.2.7 Modus Operandi in Literary Texts

4.3 The Syrian and Upper-Mesopotamian Hadda (Haddu, Hadad)

4.3.1 Hadda: The Third Millennium

4.3.2 Haddu: The First Half of the Second Millennium

4.3.3 Haddu, Teššub and Baclu: The Second Half of the Second Millennium

4.3.4 Aramaean Hadad, Assyrian Adad and Luwian Tarḩunza: The First Millennium

4.4 The Storm-God of Aleppo

Part II ( FANER 8/1)

5. Teššub, the Hurrian King of the Gods

5.1 Name and Early History

5.2 Spread of the Cult

5.3 Teššub as Head of the Imperial Pantheon of Mittani

5.4 Modus Operandi and Circle of Deities Associated with Teššub

6. Ba'lu: The Storm-God as Lord of the Gods

6.1 The Epithet $b a^{c} l u$ "Lord" as a Divine Name

6.2 Baclu of Ugarit

6.2.1 Position in the City Pantheon

6.2.2 The Mythological Texts

6.3 Baclu (Addu) at Emar

6.4 Ba'al and Ba'alšamêm in the First Millennium

7. The Anatolian Storm-Gods Taru and Tarhun(t)

7.1 Names and Strands of Tradition

7.2 Position in the Pantheon

7.3 Modus Operandi in Mythology and Ritual

8. The Victory of the Storm-God over the Sea

9. Further Gods with Storm-God Characteristics

9.1 The North-Babylonian and Assyrian Storm-God Wēr

9.2 The Babylonian God of the Western Lands Mardu-Amurru

9.3 The Anatolian Vegetation- and Storm-God Telipinu

10. A Few Remarks on Iconography

Appendix: Selected Additions and Corrections to Schwemer, Wettergottgestalten 


\section{Teššub, the Hurrian King of the Gods}

\subsection{Name and Early History}

The name of the Hurrian storm-god, Teššub, which should strictly be written Teššob according to the orthography of the Mittani letter (the variant form Teššoba occurs in the onomasticon), is without etymology, but may well be genuinely Hurrian. Teššub is attested first in Hurrian personal names of the Ur III and Old Babylonian periods. The first attestation for the storm-god himself occurs in the Hurrian inscription of Tiš-Atal of Urkeš (Ur III period), where the name of the god is already written logographically ( ${ }^{\mathrm{d}} \mathrm{IŠKUR}$ ). Nothing is known about the history of the god before Hurrian dynasties established themselves in the Upper Mesopotamian area. Teššub certainly belongs to the old Hurrian pantheon and shares his roots with the Urartian storm-god Teišeba, who is only attested in the 1st mill. Teššub was presumably at the head of the Hurrian pantheon from time immemorial as divine king. The assumption that his position of divine king accrued to him only via syncretism with Upper Mesopotamian Haddu, remains without convincing proof. The fact that Teišeba only has the second rung in the Urartian pantheon after Haldi results from secondary developments (Wettergottgestalten, 444-446).

\subsection{Diffusion of the Cult}

The main cult centre of Tešsub was Kumme, which presumably lies in the valley of the Eastern Habur. The name Kumme may perhaps be interpreted as originally Hurrian (in Akkadian then Kummu(m), in Hittite Kummiya), which would speak for an originally Hurrian character of the sanctuary. The sanctuary can be attested in the sources from the Old Babylonian to the Neo-Assyrian period and enjoyed a transregional significance similar to that of the temple of the storm-god of Aleppo. ${ }^{1}$ The storm-god sanctuary of East Tigridian Arraphe (Arraphum) is attested from the Old Babylonian period, too, and probably also had a Hurrian character even before the 15 th cent. ${ }^{2}$ With the increased establishment of

1 See Wettergottgestalten, 456ff.; on the city of Kumme cf. now also W. Mayer, "Die Stadt Kumme als überregionales religiöses Zentrum", in: Ex Mesopotamia et Syria Lux. Fs. M. Dietrich, AOAT 281, Münster 2002, 329-358.

2 For the Teššub temple in 15th and 14th cent. Arraphe see Wettergottgestalten, 463-464. 
Hurrian dynasties and finally the rise of the Empire of Mittani in the Upper Mesopotamian-North Syrian area, the cult of Teššub also spread and connected with traditions associated of old with the Semitic storm-god, Addu. Due to the lack of sources, however, it is not yet even possible to trace the developments via local case studies in any detail. The most important temples of Teššub within the realm of the Mittani empire were those of the cities Kahat, Waššukkanni, Uhuš(u)mān(i) and Irride. ${ }^{3}$

A few traces of the short-lived Hurro-Mittanian rule over Assyria are still visible in the traditions associated with Adad in the NeoAssyrian period, ${ }^{4}$ but more importantly Hurrian cultural influence extended as far as southern Anatolia and reached-mainly via Kizzuwatna - the Hittite royal family, so that significant elements, motifs and texts of Syro-Hurrian origin are identifiable in the Hittite cult from the Middle Hittite period on. The Hittite storm-god was identified with Teššub in the process; relevant religious texts (myths, hymns, prayers) were adopted and partially translated into Hittite, the name of Teššub being replaced by that of the Hittite stormgod in these cases. The Syro-Hurrian pantheon with Teššub and Heebat at its top formed an important element of the cult. ${ }^{5}$ Almost all texts providing information on the ideas associated with Teššub have been transmitted to us by Hittite scribes, be it in Hittite or Hurrian. All these texts were already the result of a comprehensive fusion of originally Syrian and Hurrian traditions, each of which was in early contact with the Assyro-Babylonian world too.

\subsection{Těšsub as Head of the Imperial Pantheon of Mittani}

According to the few sources at our disposal (mainly the Mittani dossier in the Amarna correspondence) Teššub was at the top of the official pantheon of the Mittani Empire. Nearest in rank to him was the goddess (Ištar-)Šawuška. What relationship these two divinities had to each other, is not quite clear. In the Hurrian myths and rituals known to us from Hattuša the North-Syrian Hēbat is always

3 These are the local forms of Teššub mentioned in the god list of the Šattiwaza treaty, see Wettergottgestalten, 461f.; a few more storm-god sanctuaries in what must have been cities belonging to Mittani are attested in Middle Assyrian sources (Šura, Isana, see Wettergottgestalten, 577f.).

4 See Wettergottgestalten, 482 on Šēri $(\breve{s})$ and Hurri in Assyrian sources.

${ }^{5}$ Cf. Wettergottgestalten, 498-501, and see now I. Wegner, Hurritische Opferlisten aus hethitischen Festbeschreibungen II, ChS I/3-2, Roma 2002. 
the wife, Šawuška on the other hand the sister of the storm-god. This Syro-Hurrian tradition can, however, hardly be an originally Hurrian concept. Conspicuously, forms of Šawuška were often worshipped at the side of Tešsub in the area east of the Tigris which lay under Hurrian influence, and even in Old Babylonian Upper Mesopotamia, forms of Ištar appear to have been worshipped at the side of the storm-god, albeit without Ištar-Šawuška being explicitly labelled the consort of Teššub. How the relationship between Teššub and Šawuška was conceptualised in the imperial pantheon of Mittani is not discernable from the available sources. The goddess Hēbat was surely not unknown, as Mittanian princesses have her in their names. Thus one cannot exclude that the Syro-Hurrian tradition also prevailed in the imperial pantheon of Mittani (see Wettergottgestalten, 460-462).

\subsection{Modus Operandi and Circle of Deities Associated with Tě̌šub}

The best known group of myths that feature Teššb as their protagonist is the so-called 'Kumarbi-cycle'. Only fragmentarily preserved myths from this cycle are known, exclusively on manuscripts from Hattuša, most of them Hittite translations which also translate the individual divine names into Hittite. Beside this there are also a few fragments of Hurrian versions. The whole mythic complex treats essentially one theme: the conflict between the younger divine king Teššb and his deposed father, Kumarbi, who tries by various tricks to regain the kingship over the gods. The divine kingdom is set in heaven and presided over first by the primeval god, Alalu. He is then driven out by his son, the sky-god, Anu, who himself is deposed by Kumarbi, a god of the same generation as Anu. In the struggle Kumarbi bites Anu's genitals off and thus carries the seed of powerful gods, including Teššub, within him. These are then 'born' from him and defeat him, and so Teššub becomes the new king of the gods. Teššb's earthly home is also the town of Kumme 6 in the myth, and his cosmic sphere of activities are heaven and the land. Particularly the underworld and the sea are foreign and hostile regions to him. In alliance primarily with the deities and monsters of the sea and the underworld - including a stone giant with the programmatic name Ullikummi "Destroy Kumme"Kumarbi, who was himself ascribed chthonic characteristics as a god

${ }^{6}$ For Teššub as lord of Kumme see Wettergottgestalten, 456-458. 
of cereals and as the disposessed, old king of the gods, attempts to win back the divine kingship in heaven. The narrative cycle receives suspense from the fact that Kumarbi's plans are in the short term almost successful, until Teššub finally manages to narrowly defeat his various opponents. The cycle perhaps ended with a struggle between Teššub and the sea-god, who may have been allied to Kumarbi, from which Teššub definitively emerges as the victorious king of the gods (for the motif of the storm-god's victory over the sea, cf. also 8.). ${ }^{7}$

The group of deities associated with Teššub according to the Kumarbi-cycle corresponds broadly to that known from other religious texts of Hurrian provenance: He was a son of Anu and Kumarbi; a Hurrian invocation labels Kumarbi as Teššub's "mother" in harmony with the 'Song of Kingship in Heaven' from the Kumarbi-cycle. In $K U B$ 33, 89+: 6' Teššub is apparently called a son of the moon-god, but this attestation is still isolated and its significance remains unclear for the time being. Brother and sister of Teššub were Šawuška and Tašmišu (Hittite Šuwaliyatt); the latter is is also called Teššb's vizier - a position which is occupied by the god Tēnu in the ritual texts, perhaps following an Aleppine traditon. ${ }^{8}$ The chariot of Teššub was pulled by two divine bulls, as frequently attested in Hittite and North-Syrian art. In the Song of Ullikummi these bulls are called Šèrišu and Tilla. But most frequently it is Hurri (older Hurra), also a divine bull, who stands beside Šēri(̌̌s), not Tilla, who is attested as an important independent god in the region of Nuzi in the 15 th cent. While Šèri( $\breve{s})$ partly appears as an

7 See Wettergottgestalten, 446-454. In the meantime more fragments have been identified as (possibly) belonging to the Kumarbi-cycle, see D. Groddek, “,Diese Angelegenheit] höre die Ištar von Ninive nicht!"", WdO 31 (2000-2001) 23-30 and A. Archi, "Ea and the Beast. A Song Related to the Kumarpi Cycle", in: Silva Anatolica. Studies M. Popko, ed. P. Taracha, Warsaw 2002, 1-10. For Hurrian fragments see M. Giorgieri, "Die hurritische Fassung des Ullikummi-Liedes und ihre hethitische Parallele", in: Akten des IV. Internationalen Kongresses für Hethitologie Würzburg, 4.-8. Oktober 1999, StBoT 45, Wiesbaden 2001, 134-155 (Ullikummi, cf. Wettergottgestalten, 457 fn. 3778), M. Dijkstra, "The Myth of apši "the (Sea)dragon" in the Hurrian Tradition", UF 37 (2005) 315-328 (Hedammu) and, generally, ChS 1/6. For the first song of the cycle see now C. Corti, "The So-called "Theogony" or "Kingship in Heaven". The Name of the Song", SMEA 49 (2007) 109-121.

${ }^{8}$ For Teššub's filiation see Wettergottgestalten, 454f., 451 fn. 3736, for Tašmišu and Tēnu see ibid., 448 fn. 3719 and 500f. Note that a "divine priest named

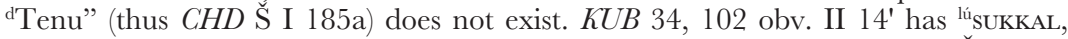
not lúSANGA, as all other parallel texts (also syllabically $\check{s} u-u k-k a l-l i$ ). For Šawuška and Hēbat see Wettergottgestalten, 460-461. 
independently acting god, but mainly as the mediator between humans and his lord Teššub, Hurri is only mentioned at the side

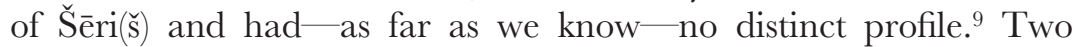
further side-kicks of Teššub were the mountain-gods Hazzi (Cassius) and Nanni (Anti-Cassius?); they play no role in the Kumarbi-cycle, but are often named in the offering lists directly after Šèri( $\breve{\mathbf{s}})$ and Hurri. ${ }^{10}$ Otherwise, the South-Anatolian bull- and mountain-god Šarrumma, who occupied an important position in the Hittite pantheon of the 13th cent., was known as the son of Teššub and Hēbat.

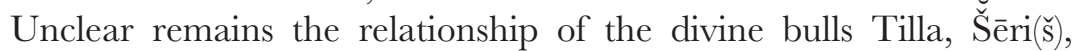
Hurri and Šarrumma to the divine bull-calf Būru, who is subordinate to Adad primarily in the Aramaean milieu of the Neo-Assyrian and Late Babylonian periods; whether this bull-god Būru was somehow related to the god Apladad, the Adad-son of 1st mill. Aramaean religion (cf. 4.2.3), is unknown too. ${ }^{11}$

The narratives of the multi-tablet series "Release", which have been preserved in a bilingual, Hurrian-Hittite version, are fraught with numerous difficulties of interpretation due to their overall very fragmentary state of preservation. ${ }^{12}$ Here, too, Teššub appears as lord of the gods. The beginning of the proemium refers directly to Teššub as lord of Kumme. In one episode Teššub demands the release of prisoners from Megi, the ruler of Ebla, and threatens otherwise the destruction of the city. The city-elders respond to this approach in the form of ironic questions, saying that it is quite improbable that the powerful Teššub would have solidarity with the prisoners. ${ }^{13}$ In another episode Teššub is a guest in the underworld, where the goddess of the underworld receives him with a celebration. Whether this episode ends in an imprisonment of Teššub in the underworld and how such an imprisonment of Teššb in the underworld is connected to the argument with the demand for the release of the prisoners in Ebla must remain open questions for the moment. It is even less sure whether some temporary

9 For the divine bulls associated with Teššub see Wettergottgestalten, 477-487.

10 For Hazzi and Nanni see Wettergottgestalten, 228f., 233, 480, 514f. with fn. 4185 and 516 with fn. 4194 with further literature.

11 For Būru see Wettergottgestalten, 487-489 and K. Radner, Die neuassyrischen Texte aus Tall Šèh Hamad, Berlin 2002, 16.

12 See most recently G. Wilhelm, "Das hurritisch-hethitische 'Lied der Freilassung", in: TUAT. Ergänzungslieferung, ed. O. Kaiser, Gütersloh 2001, 82-91.

${ }^{13}$ For this interpretation see Wilhelm, loc. cit., and idem, "Die Könige von Ebla nach der hurritisch-hethitischen Serie 'Freilassung", AoF 24 (1997) 277-293. 
imprisonment of Teššub in the underworld should be put in the context of the conflict between Kumarbi and Teššub known from the Kumarbi-cycle, or, for that matter, in the context of Ba'lu's dying and rising in the Ugaritic Balu-cycle. At any rate it emerges clearly from the bilingual, too, that the underworld did not belong to the proper domain of Teššub. He dines there according to the Allani-episode beside the primordial gods who he himself had once banished to the underworld. ${ }^{14}$

\section{Baclu: The Storm-God as Lord of the Gods}

\subsection{The Epithet ba'lu, "lord", as Divine Name}

The use of the epithet bèlu, baclu "lord" as the proper name of a particular god is attested for different gods in various epochs of the ancient Near East. Either these are abbreviations of the frequently occurring type of epithet, connected with all sorts of gods, "lord of (place-name)", or it is the labelling of particular gods as lord (of the gods) par excellence (like Bēl for Marduk). Even the endingless form $B a^{c} a l$ is already attested in the Early Dynastic period (god-list from Tell Abū Șalābīh). In the pre-Sargonic calendars of Ebla and Tell Beydar there is a month-name named after a god only referred to as Baclu or Bèlu ( ${ }^{\mathrm{d}} b e-l \hat{\imath}$. In Tell Beydar this god also occurs in the name of a gate. ${ }^{15}$ Which god is hidden behind these epithets is not easy to decide. In view of the fact that the 'New Calendar' from Ebla had a month of Hadda beside the month of $\mathrm{Ba} \mathrm{Clu}$ and that otherwise no recognisable connections between Hadda and the appellation $B a^{c} l u\left(B a^{c} a l\right)$ from this period exist, a simple equation of this "Lord" with the Late Bronze Age storm-god Ba'lu is out of the question. The element baclu in Ebla onomastics and similarly in later Amorite onomastics should be understood as an epithet and address form that can stand for different deities, not as an actual name of a single god. It appears therefore unlikely that $B a^{c} l u$ as found in the Early Dynastic texts from Ebla, Tell Beydar and Tell Abū Șalābīh represents the immediate precursor of the stormgod Balu of late 2nd and 1st mill. Syria. The overall evidence rather points to Ballu developing in the course of the late 16th and

14 See Wettergottgestalten, 455-456 with fn. 3761-63.

15 See W. Sallaberger, "Calendar and Pantheon", in: W. Sallaberger e. a., Administrative Documents from Tell Beydar, Subartu 2, Turnhout, 85-87. 
15th centuries on the Syro-Palestinian coastal strip from an epithet of the storm-god Haddu to his primary name, independently from the gods called $B a^{c} l u$ or $B a^{c} a l$ about a thousand years earlier. Conversely Haddu serves as an epithet of Baclu in Ugaritic mythology. Particularly telling in this regard are not only the cuneiform sources from Syro-Palestine itself (mainly the Amarna-Correspondence and texts from Tell Ta'anakh), ${ }^{16}$ but also the rendering of the name of the Syrian storm-god in contemporary Egyptian sources. The theological background for this development may well have been the prominent position of the god Haddu in the panthea of SyroPalestine, which had him as the lord (of gods) per se. ${ }^{17}$ The use of the name Baclu then spread in the 14th and 13th centuries as far as Emar on the Middle Euphrates without ever fully replacing Adad (Addu) as the storm-god's name (infra, 6.3). Further East the usage of the name Balu was never adopted.

\section{$6.2 B a^{c} l u$ of Ugarit}

Thanks to the texts found in the city of Ugarit we are by far best informed about the storm-god Balu (Haddu) worshipped in the city of Ugarit. But the abundance of information available for $\mathrm{Ba}$ lu of Ugarit and Ba'lu of Mt. Șapuna (Hazzi, Zaphon, Cassius, modern Gebel al-Aqra') should not distract from the fact that the texts from Ugarit represent the tradition of only one of the most important city-centres of Late Bronze Age Syro-Palestine. We know almost nothing of the myths and cults of the later Phoenician cities of Byblos, Sidon and Tyre or of the land of Amurru. On the other hand one has to take into account that especially the cult of Ba'lu Șapuna had trans-regional significance.

${ }^{16}$ For the texts found at Tell Taanakh see now W. Horowitz-T. Oshima, Cuneiform in Canaan. Cuneiform Sources from the Land of Israel in Ancient Times, Jerusalem 2006, 127-151.

17 For this overall interpretation of the evidence see Wettergottgestalten, 502-511; for a different view see G. Pettinato, "Pre-Ugaritic Documentation of Ba'al", in: The Bible World. Studies C.H. Gordon, ed. G. Rendsburg e.a., New York 1980, 203209, and W. Herrmann, Art. "Baal", Dictionary of Deities and Demons in the Bible, ed. K. van der Toorn e.a., Leiden e.a. ${ }^{2} 1999$, 132-139. For the problem of the identification of the god(s) behind the epithet Balu ( ${ }^{\mathrm{d}}$ etc.) cf. also Feliu, Dagan, 7-41. For the semantics of the divine name $B a^{c} a l$ in North-West Semitic languages cf. now H.-P. Müller, "Der Gottesname $B^{c} l$ und seine Phraseologien im Hebräischen und im Phönizisch-Punischen", 7SS 50 (2005) 281-296. 


\subsubsection{Position in the Pantheon of the City}

Baclu embodies the type of young king of the gods who attains the worthiness of kingship among the gods by struggle, but who remains at the same time in principle subordinated to his father 'Ilu, the inactive father of the gods who is dependent on the deeds of his son (cf. e.g. the relationship between Ninurta and Enlil in Nippur). Both gods stood with their different functions together at the top of the local pantheon and were addressed by the kings as the main gods of the city (cf. CAT 1.14 obv. II 22ff.). The special role of the young king of the gods, Balu, is that of representing the interests of the earthly king before the divine father (cf. CAT $1.15 \mathrm{obv}$. II $11 \mathrm{ff}$.). The close relationship between the human king and his divine counterpart is also illustrated by the fact that the mythological episodes dealing with the burial of $\mathrm{Ba}$ lu resemble rites performed at the burial of Ugaritic kings. ${ }^{18}$ Ba'lu's position at the top of the city's pantheon is clearly reflected by the numerous personal names formed with his name. ${ }^{19}$ The two temples on the acropolis of Ugarit surely are the sanctuaries of 'Ilu and Ba'lu. It was probably 'Ammu-rāpi of Ugarit who renovated the temple of Ba'lu and sent a message to Egypt requiring craftsmen for his work on the building and a votive statue of the Egyptian king. ${ }^{20}$

Ba'lu consequently usually occupies the first rank among the younger gods in the offering lists of Ugaritic rituals, while the older gods 'Ilu'ibi, 'Ilu and Dagān precede him. The cult distinguishes between Ba'lu of the city of Ugarit and Balu of Mt. Sapuna. It is unsure whether both possessed a sanctuary. Probably the main temple of Baclu on the acropolis could also be called the temple of Balu Sapuna, as the mythical home of Balu (of Ugarit) was definitely

18 See Wettergottgestalten, 532f. For the last point see D.M. Clemens' important article "KTU 1.45 and 1.6 I 8-18, 1.161, 1.101", UF 33 (2001, publ. 2002) 65116, and cf. also M.S. Smith, "The Death of 'Dying and Rising Gods' in the Biblical World. An Update with Special Reference to Baal in the Baal Cycle", SFOT 12 (1998) 289-309 and the critique of this article by T.N.D. Mettinger, The Riddle of Resurrection. "Dying and Rising Gods" in the Ancient Near East, Stockholm 2001, 64-66.

${ }_{19}$ See Wettergottgestalten, 525-532; note that the name ${ }^{\mathrm{d}} \mathrm{IS} K U \mathrm{~K}-i a_{8}$ compared to Addaya (526 with fn. 4264) must be read Baluya (brother and predecessor of Aziru of Amurru).

${ }^{20}$ See Wettergottgestalten, 512f.; the important letter of the Egyptian king has now been published by S. Lackenbacher in Études ougaritiques I. Travaux 1985-1995, ed. M. Yon-D. Arnaud, RSOu 14, Paris 2001, 239-248, for a recent German translation see Schwemer, TUAT.NF 3, ed. B. Janowski-G. Wilhelm, Gütersloh 2006, 256-258 (with further literature). 
meant to be Mt. Șapuna. If both Ba lu manifestations were named beside each other, Balu Șapuna had rank over Balu of the city Ugarit. ${ }^{21} \mathrm{Ba}$ lu of Halab too was worshipped at Ugarit. He is the highest-ranking storm-god to receive sacrifices during the hiyaru-ritual at Ugarit, named before Balu of Mt. Șapuna. Both storm-gods receive a bull and a sheep on this occasion, an honour they share with only one other god in the list: the god Šarraššiya $\left(\underline{t} t \underline{t} y,{ }^{\mathrm{d}} \check{s} a r\right.$ $r a-\breve{s i}-i a)^{22}$ named directly after the two storm-gods. This god is so far not attested otherwise, but there can be little doubt that he is a personification of Hurrian šarrǎšse- "kingship", a term that is frequently used - in the Hurrian essive case - as 'offering term' in Hurro-Hittite rituals: ̌̌arrašsizya "for kingship". ${ }^{23}$ It is apparently this 'offering term' in its typical form that was personified and turned into a deity of its own. The sacrifices to this deity directly after the two storm-gods seem to suggest that the hiyaru-festival at Ugarit was especially performed with regard to (the Aleppine) Ba'lu's kingship over the gods.

\subsubsection{The Mythological Texts}

A group of fragmentary mythological texts in the Ugaritic language, the so-called 'Ba'lu-cycle', is concerned with the struggles of Ba'lu for kingship among the gods. His rivals in this struggle all come from the younger generation of gods, while the father of the gods,

${ }^{21}$ For the evidence from the ritual texts, offering lists and related school texts see Wettergottgestalten, 514-525. For the texts themselves see now the comprehensive treatments by D. Pardee. Les textes rituels, RSOu 12, Paris 2000 (came too late to be taken into account for Wettergottgestalten) and idem, Ritual and Cult at Ugarit, Writings from the Ancient World 10, Atlanta 2002. For the storm-god of Mt. Zaphon in the Hellenistic and Roman times (Zeus Kasios) see now K. Ehling D. Pohl-M.H. Sayar, Kulturbegegnungen in einem Brückenland. Gottheiten und Kulte als Indikatoren von Akkulturationsprozessen im Ebenen Kilikien, Asia Minor Studien 53, Bonn 2004, 174ff.

${ }^{22}$ For the text and its interpretation see Wettergottgestalten, 521f. The reading of the name trty (CAT 1.148 rev. 28) has now become clear. The syllabic parallel text RS 92.2004 has “̌̌ar-ra-ši-ia (see D. Arnaud, "Textes administratifs", in: Études Ougaritiques I. Travaux 1985-1995, ed. M. Yon-D. Arnaud, RSOu 14, Paris 2001, 323-326 fn. 23 [RS 92.2004 // 92.2009], cf. also D. Pardee, ZNES 61 [2002] 119-120 and idem, Ritual and Cult, 12-19). The logographic (?) writing of the same name, ${ }^{\mathrm{d}}{ }_{\mathrm{IM}}$ ?.TUR in RS 26.142 obv. 8, is unclear to me (despite D. Arnaud's remarks, loc. cit., 325).

${ }^{23}$ For the attestations see $C H D \breve{\mathrm{S}} 245$. Note that there is no "storm-god of šarrǎšizya" as implied by D. Arnaud, loc. cit., 325. Whether Šarraššiya himself had attributes of a storm-god we do not know; he certainly his a personification of one of the basic motifs of the Syro-Hurrian storm-god's mythology. 
'Ilu, essentially watches the struggles among the younger generation, without his own position being put in question by this. The fact alone, however, that $\mathrm{Ba}$ lu has to fight against other rivals for the kingship, which office is finally approved by 'Ilu, suggests a certain tension between the father of the gods and the storm-god, which reminds one slightly of the configuration of the conflict between Kumarbi and Teššb. In the Ugaritic myth, too, the seagod (Yammu) is a main enemy of the storm-god. 'Ilu installs Yammu as king for unknown reasons and subordinates Baclu to him. Balu defeats Yammu in battle and thus secures the kingship for himself (cf. infra, 8.). Here begins the second large part of the Balu-cycle, which is devoted to the building of a palace and the associated definitive confirmation of Ba'lu's kingship by 'Ilu. The third large narrative of the Balu-cycle describes the defeat of the storm-god at the hands of the god of death, Môtu. Ba'lu is buried and must descend into the underworld powerless. He dies and takes the storms and rains with him. The scene of Ba'lu's burial is only briefly referred to in the Ba'lu-cycle itself, but other excerpts from mythological texts seem to indicate that fuller descriptions of the treatment of the deceased Ba'lu existed. ${ }^{24}$ Only after Ba'lu's sister 'Anatu has destroyed Môtu, does Ba'lu re-emerge from the underworld with his abundance. The cyclical plot of the story suggests a seasonal interpretation. During the winter rain-period $\mathrm{Ba}$ lu is among people and in heaven, the summer dry-season is brought about by his sojourn in the world of the dead. Parts of the text indicate that the myth concerns disastrous droughts occurring at long intervals, but of course even such disasters basically move within the basic seasonal framework. In contrast to the myth about $\mathrm{Ba}^{\mathrm{C}} \mathrm{lu}$ and Yammu, the story about Ba'lu and Môtu cannot be connected with earlier material associated with Haddu, Teššub or Iškur-Adad (but cf. supra, 3.4 and 5.4). Rather this part of the Baclu-cycle shows a relationship with myths about other dying and returning vegetation gods (esp. Dumuzi-Tammuz and Adonis). ${ }^{25}$ But similar stories about

24 See D.M. Clemens, UF 33 (2001, publ. 2002) 65-116 (cf. 6.2.1). For the description of Balu in the difficult text CAT $1.101 \mathrm{cf}$. also infra, 10.

25 For the storm-god's role in the Ugaritic (and Canaanite) mythological texts see Wettergottgestalten, 532-542; for the myth of Ba'lu's dying and rising and the motif of dying and rising gods generally see now T.N.D. Mettingers comprehensive study The Riddle of Resurrection. "Dying and Rising Gods" in the Ancient Near East, Stockholm 2001, which unfortunately appeared only after Wettergottgestalten had gone to press. 
the storm-god's defeat and imprisonment in the underworld formed part of other contemporary Canaanite myths too, as the 'Elkuniršamyth' shows. The last passage of this myth that is only preserved in Hittite translation relates how an injured $\mathrm{Ba}$ lu is treated, "recreated" (appa šamnai-) by the birth goddesses and exorcised by a number of exorcists. It seems that the storm-god had been forced to the underworld too, but on the whole the text is much too fragmentary to allow far-reaching interpretations. ${ }^{26}$ It should be noted, however, that the motif of disappearing gods in genuinely Anatolian mythology (Telipinu myth etc.) is in various aspects significantly different from the Ugaritic Balu-myth; it seems unlikely, also with regard to the general lack of Hittite influences in Syro-Mesopotamian mythology, that these Anatolian myths and rituals served as a model of the story about Ba'lu's death and return. ${ }^{27}$

Not explicitly attested in the texts is the worship of Balu as protective deity of sea-faring. The great significance of sea-trade for the city of Ugarit, the role of Ba'lu as victor over Yammu and the monsters of the sea, the discovery of stone anchors as votive gifts in the area of the Ba'lu temple (as in other sanctuaries on the SyroPalestinian coast too), ${ }^{28}$ as well as the probable function of the $\mathrm{Ba}$ lu temple which rises high above the city as an orientation point (and light-house?) for sailors make it plausible, however, that $\mathrm{Ba}$ lu was ascribed this function too. ${ }^{29}$

As a young god, Balu did not have a consort in a real sense. The mythological texts, however, appear to describe sexual encounters both with 'Attartu and with Balu's sister 'Anatu. In the HellenisticRoman period Astarte and Atargatis, presumably a syncretism of 'Attartu and 'Anatu, were worshipped as consorts of the Syrian storm-gods. Neither 'Anatu nor 'Attartu, however, are named as mothers of Ba'lu's three daughters, Pidray, Arșay and Tallay. Pidray

${ }^{26}$ For the Elkunirša-myth cf. H.A. Hoffner Jr., Hittite Myths, Writings from the Ancient World 2, Atlanta ${ }^{2} 1998,90-92$, G. Beckman, "Elkunirša and Ašertu", in: Context of Scripture I, ed. W.W. Hallo, Leiden 1997, 149, and now also V. Haas, Die hethitische Literatur. Texte Stilistik, Motive, Berlin-New York 2006, 213-216.

27 See Wettergottgestalten, 538 with fn. 4326, and cf. now also Mettinger, The Riddle of Resurrection, 76-80.

${ }^{28}$ For a comprehensive study of the stone anchors see H. Frost, "Anchors Sacred and Profan. Ugarit-Ras Shamra, 1986; the stone anchors revised and compared", in: Arts et industries de la pierre, ed. M. Yon, RSOu 6, Paris 1991, 355-408.

${ }_{29}$ Perhaps the famous seal from Tell Dab`a can be interpreted this way, too; thus among others I. Cornelius-H. Niehr,Götter und Kulte in Ugarit, Mainz 2004, 47,72 . 
herself is equated with Heebat, the North-Syrian consort of Teššubthis too being an indication that the Ugaritic Ba'lu did not have a wife in any real sense. ${ }^{30}$ 'Ilu is named as the father of $\mathrm{Ba}$ 'lu throughout. Only in two frozen epithets Ba'lu is also called "Son of Dagān", following an older Syro-Hurrian tradition. ${ }^{31}$ On the level of myth, Dagān does not play a role and appears to have been completely absorbed by Ugaritic 'Ilu.

\subsection{Baclu (Addu) at Emar and Other Cities on the Middle Euphrates}

In the 14th and 13th centuries the use of the name Balu spread as far as Emar on the Middle Euphrates (and places in its vicinity), where the names Addu, Balu and Teššub were used beside each other depending on the linguistic context - a situation that is also reflected in the contemporary glyptic. ${ }^{32}$ Unfortunately almost nothing is known about the mythology of the storm-god at Late Bronze Age Emar, and we get only little insight into how the different traditions connected with Addu, Teššub and Baclu coexisted or were blended in this area. Traditionally Balu (Addu), "the lord of Imar", seems to have been the most important god of the city ranking only after the more senior Dagān, while the citygod NINURTA ${ }^{33}$ receives the position after the storm-god in the offering lists. Probably Hēbat was worshipped as consort of the storm-god, and while Aštartu had a high rank in the local pantheon as well, claims that she was worshipped as Ba'lu's consort are based on little evidence. Possibly her relationship can be compared to that between Addu (Teššub) and Ištar (Šawuška) in the Old Babylonian period and in the 16th and 15th cent. ${ }^{34}$ The installation ritual for Ba'lu's high priestess is preserved in three versions, and other texts

30 For the goddesses associated with Baclu see Wettergottgestalten, 542-546.

31 Cf. Teššub as son of Kumarbi, who is equated with Dagān, see supra, 4.3.2.

32 See Wettergottgestalten, 548-552; for the depiction of the storm-god on the Emar seals and the various traditions apparent in the different styles that can be observed see D. Beyer, Emar IV: Les sceaux, OBO SA 20, Fribourg - Göttingen 2001, 299 306.

33 For ninurta cf. J.G. Westenholz, "Emar - the City and its God", in: Languages and Cultures in Contact. Proceedings of the 42th RAI (OLA 96), ed. K. van LerbergheG. Voet, Leuven 1999, 145-67.

34 In principle one cannot exclude that Hèbat was regarded as Ba'lu's regular consort and Aštartu as his mistress (cf. the relationship between Nabû, Tašmētu and Nanaya in 1st mill. Borsippa), but we have not enough evidence for any conclusions of this kind. 
inform us about the cult calendar of the city and its storm-god temple, but reveal little about Baclu himself. ${ }^{35}$

\subsection{Bácal and Báalšamêm in the First Millennium}

The use of the original epithet Balu as personal name of the Semitic storm-god, Haddu, as primarily attested in texts from Ugarit for the Late Bronze Age, continued without interruption in the Iron Age cultures of Syro-Palestine and South Anatolia. The storm-god is always called Ba'al in Phoenician texts; the 'Canaanite' stormgod is also called $\mathrm{Ba}^{\mathrm{c}}$ al in the Old Testament. ${ }^{36}$ By contrast the inherited Semitic name of the storm-god lived on in the form Hadad (Hadda) in the Aramaean dominated interior of Syria and in Upper Mesopotamia (see 4.3.4). Of course the name $\mathrm{Ba}^{c}$ al did not always stand for a storm-god, for, as in earlier periods, particularly in connection with a place-name it could serve as an independent epithet of a local leading deity of any kind. In those regions which were in contact with Babylonia, Bēl(-Marduk) was then appropriated and fused with the Syrian Bacal (cf. the god Bel $[<\mathrm{Bol}]$ in Palmyra). ${ }^{37}$

The storm-god was always and everywhere considered as one of the sky-gods per se. The most important manifestation of the Hittite Tarhun $(\mathrm{t}$ ) was regularly called "storm-god of heaven" (from the Old Hittite period; similarly to be assumed for Hattic Taru). Already from the Old Babylonian period the same epithet "of heaven" can be attested on the Middle Euphrates and in the Upper MesopotamianAssyrian area for Haddu or Adad (similarly for other sky-gods: Sîn, Šamaš, Ištar, later Anu). ${ }^{38}$ The epithet always refers to the main manifestation of the individual deity (residing in heaven) by contrast to the diverse local manifestations, which were associated with particular earthly places. It is no accident that the lists of oath-gods in treaties, which were supposed to bind people from different regions, like to name exactly those comprehensive "heavenly

35 See Wettergottgestalten, 553-573; D. Fleming's important study Time at Emar: The Cultic Calendar and the Rituals form the Diviner's Archive, MC 11, Winona Lake 2000, appeared too late to be fully appreciated in Wettergottgestalten. The texts from Tell Munbaqa are now availabe in a comprehensive edition: W. Mayer, Tall Munbaqa -Ekalte II: Die Texte, WVDOG 102, Saarbrücken 2001.

36 See e.g. M.S. Smith, The Early History of God. Tahwe and the Other Deities of Ancient Israel, Grand Rapids - Cambridge 22002 with further literature.

37 Cf. Wettergottgestalten, 503 fn. 4110 with literature.

38 See Wettergottgestalten, 284, 714b, cf. now also P.-A. Beaulieu, The Pantheon of Uruk during the Neo-Babylonian Period, CM 23, Leiden-Boston 2003, 346f.). 
manifestations" at the very beginning of the lists, before the respective local manifestations.

In the Hieroglyphic Luwian inscriptions of the first half of the 1st mill. the storm-god Tarhunza is very often supplied with the epithet "of heaven" (tipasasis Tarhunzas), without a divine manifestation different from the simple Tarhunza being meant by it (cf. for example the alternating use of tipasasis Tarhunzas and simple Tarhunzas in the inscriptions of Katuwa from Karkamiš). Apparently in the Phoenician-speaking area the phrase blšmm "Bacal of Heaven", which also serves to translate tipasasis Tarhunzas in the PhoenicianLuwian bilingual of Karatepe, developed into an independent manifestation of the storm-god that occupied a prominent position especially in the Syro-Palestinian religions of the Hellenistic and Roman periods. How far the emancipation of $\mathrm{Ba}^{\mathrm{c}}$ alšamêm into an independent deity is due to Anatolian-Luwian traditions is still unclear. At any rate the assumption of a simple identity of Tarhunza with the epithet tipasasis on the one hand and the independent Ba'alšamêm on the other is problematic, despite the Karatepe bilingual. It seems more plausible to view Luwian tipasasis Tarhunzas as one of the points of departure for the later independent development of the deity $\mathrm{Ba}^{c}$ alšamêm within Phoenician religion. The cult of the god is, however, not restricted to Phoenician-speaking territory. The name is adapted in Aramaic as Ba'alšamīn as well. Considering the chronological distribution of the attestations for Hadad and $\mathrm{Ba}^{c}$ alšamīn in the area of Aramaean cultural influence, we get the impression that the name $\mathrm{Ba}^{c}$ alšamīn takes over from the name Hadad regionally in the course of the Persian period at least on the level of official religion, which is not too surprising in view of the common roots and similar profile of the two gods. In the first half of the 1st mill. there are no attestations for the combination of the two gods; however, the state of the sources is on the whole very fragmentary. The god $\mathrm{Ba}^{c}$ alšamīn appears to have been unknown in this period beyond those areas of Syria and Upper Mesopotamia immediately juxtaposed to the Phoenician-speaking territory. The Aramaic papyrus pAmherst 63 (about 3rd cent. B.C., Upper Egypt) names in col. xv and xvi Hadad (or Hadda) in synonymous parallelism with $\mathrm{Ba}^{\mathrm{c} a l s ̌ a m i ̄ n}$ and thus gives us a secure terminus post quem for the identification of the two gods. ${ }^{39}$

39 On Ba'alšamêm see now the comprehensive review of H. Niehr (Bácalšamem. Studien zu Herkunft, Geschichte und Rezeptionsgeschichte eines phönizischen Gottes, OLA 123, Leuven 2003) with a slightly different view of the early history of the god. 


\section{The Anatolian Storm-Gods Taru and Tarhun(t)}

\subsection{Names and Strands of Tradition}

The world of religious ideas that we encounter in texts of the Hittite period is characterised by multiple layers of tradition, though it is not always possible to isolate the different individual traditions and to create a coherent complete picture of each of the specific strands of tradition in its 'original' form. This is particularly true of the relationship between Old Anatolian-Hattic religious traditions and such ideas that already belonged to the speakers of the Anatolian branch of Indo-European prior to their migration into Anatolia. The influence of Hattic traditions on what became Hittite culture is especially marked in the field of religious ideas and not least the world of the gods, so that a separate investigation of the Hattic storm-god on the one hand and the Hittite-Luwian(-Palaic) stormgod on the other would be impossible. There is no adequate comprehensive study of the Anatolian storm-gods, one of the more urgent desiderata of Hittitology. Thus the following observations can only be provisional. ${ }^{40}$

40 The relevant chapter in Green, Storm-God (pp. 89-152) relies uncriticallyand apparently without much first-hand knowledge of the sources themselves - on the problematic study of H.J. Deighton (The 'Weather-God' in Hittite Anatolia. An Examination of the Archaeological and Textual Sources, BAR International Series 143 , Oxford 1982); it is thus largely flawed and outdated; note that important critical reviews of Deighton's study are missing from the bibliography (V. Haas, OLZ 80 [1985] 461-463, O. Gurney, fRAS 1983/2, 281-282), while G. Beckman, "The Anatolian Myth of Illuyanka", FANES 14 (1982) 11-25 was used, but the critical remark on p. 23 fn. 80 apparently went unnoticed. The recent overview-works on Hittite religion (esp. V. Haas, Geschichte der hethitischen Religion, HdO I/15, Leiden 1994, M. Popko, Religions of Asia Minor, Warsaw 1995, both missing from Green's bibliography, and, more recently, M. Hutter, "Aspects of Luwian Religion", in: The Luwians, ed. H.C. Melchert, HdO 1/68, Leiden-Boston 2003, 211-280, esp. 220-224) do offer important information but naturally are kept general and sometimes their claims are hard for the user to verify. Instructive shorter studies are particularly Ph.H.J. Houwink ten Cate, "The Hittite Storm God: His Role and His Rule According to Hittite Cuneiform Sources", in: Natural Phenomena. Their Meaning, Depiction and Description in the Ancient Near East, ed. D.J.W. Meijer, Amsterdam e.a. 1992, 83-148 and J. Klinger, Untersuchungen zur Rekonstruktion der hattischen Kultschicht, StBoT 37, Wiesbaden 1996, 147-152 (both missing from Green's bibliography, too) as well as a number of studies on local manifestations of the Hittite storm-god: J. Glocker, Das Ritual für den Wettergott von Kuliwišna. Textzeugnisse eines lokalen Kultfestes im Anatolien der Hethiterzeit, Eothen 6, Firenze 1997, M. Popko, Zippalanda. Ein Kultzentrum im hethitischen Kleinasien, THeth 21, Heidelberg 1994, R. Lebrun, "Lawazantiya, foyer religieux kizzuwatnien", in: Florilegium anatolicum. Mélanges E. Laroche, ed. E. Masson, Paris 1979, 197-206, idem, Samuha, foyer religieux 
The Hattic storm-god was called Taru; his name is written syllabically and with the usual Sumerograms ( ${ }^{\mathrm{d}} \mathrm{IS}$ KUUR, $\left.{ }^{\mathrm{d}} 10\right)$. It is unclear whether the Hattic name of the god, who is also represented theriomorphically as a bull, is to be connected with the bull-word as attested in Semitic and Indo-European languages. ${ }^{41}$ The name of the Hittite-Luwian storm-god is attested in various forms, all of which ultimately go back to the Indo-European base $* t_{0} h_{2^{-}}$, which is continued in Hittite as tarh- "be powerful", "overcome". ${ }^{42}$ The most important form of the name in Cuneiform Luwian is Tarhunt$(<*$ tarhuwant-), a participial form which has a Vedic cognate with the meaning "storming along". In Hieroglyphic Luwian the nominative form Tarhunz (Tarhunt-s) is secondarily thematised in $-a$, whereby the stem as used in the nominative and accusative are produced (Tarhunza-). Beside the participial form the shorter form Tarhu- occurs, which especially in Hittite is then extended to the (secondarily thematised) n-stem Tarhunn(a)-, though Hittite texts also use frequently the Luwian form Tarhunta- with $a$-thematisation. Syllabic writings are extremely rare, and as a rule logograms (with phonetic complements) are used: ${ }^{\mathrm{d}}$ IŠKUR, ${ }^{\mathrm{d}} 10$, Hieroglyphic ${ }^{\text {DEUS }}$ TONITRUs (with special logograms for Teššub: ${ }^{\text {DEUS }}$ L.318, ${ }^{\text {DEUS }}$ FORTIS). ${ }^{43}$ The god Tatta is not a storm god, but a mountain-god, and Tatta is not a reading for ${ }^{\mathrm{d}}$ IŠKUR or ${ }^{\mathrm{d}} 10 .{ }^{44}$ The name of the Palaic stormgod cannot be read for certain. M. Popko proposes Ziparwa, who is prominent in the Palaic pantheon, as the reading of the logographically written ${ }^{\mathrm{d}} \mathrm{ISKKUR}$ (resp. ${ }^{\mathrm{d}} 10$ ) in the relevant contexts, but

de l'empire hittite, PIOL 11, Louvain-la-Neuve 1976, V. Haas, Der Kult von Nerik. Ein Beitrag zur hethitischen Religionsgeschichte, StP 4, Roma 1970 (only the last item of this list is referred to by Green).

${ }^{41}$ Cf. Wettergottgestalten, 126 fn. 871.

42 See F. Starke, Untersuchung zur Stammbildung des keilschrift-luwischen Nomens, StBoT 31, Wiesbaden 1990, 136-145, J.D. Hawkins, in: S. Herbordt, Die Prinzen- und Beamtensiegel der hethitischen Großreichszeit auf Tonbullen aus dem Nişantepe-Archiv in Hattusa, Mainz 2005, 295.

${ }^{43}$ The interpretation of the writing of the name of a god, iconographically identified as a storm-god, in the Aleppo temple with a mace symbol is still unclear and without parallel. G. Bunnens proposes tentatively that the god in question might be a personified weapon of the storm-god depicted in the fashion of the storm-god (see "The Storm-God in Northern Syria and Southern Anatolia from Hadad of Aleppo to Jupiter Dolichenus", in: Offizielle Religion, lokale Kulte und individuelle Religiosität, ed. M. Hutter-S. Hutter-Braunsar, AOAT 318, Münster 2004, 63-64).

44 Contra Green, Storm-God, 128, who without any explanation still refers to "Datta" as one of the names of the "Luwian Storm-gods". 
this remains without certain proof. ${ }^{45}$ It is conspicuous that the name of the Hittite-Luwian storm-god is an appellative without parallel in the other Indo-European panthea and, at the same time, sounds similar to Hattic Taru. Thus it is conceivable that the name was a new formation under the influence of Hattic Taru. ${ }^{46}$ Hittite-Luwian Tarhun( $(\mathrm{t})$ would then be nothing more than the Old-AnatolianHattic storm- and bull-god as adapted by the Luwians and Hittites.

One of the important gods worshipped in the city of Kaneš (Hittite Neša) during the Old Assyrian period was the god Nipas (Ni-pá-as), a deity so far not attested after the Kültepe II period (neither in Old Assyrian Ib texts nor in Hittite texts). G. Kryszat recently pointed out that while a number of priests of the local Anatolian storm-god (always written ${ }^{\mathrm{d} I S ̌ K U R}$ ) are mentioned in documents of the later phase of Old Assyrian trade at Kaneš (Ib), ${ }^{47}$ no certain attestations for the local Anatolian storm-god written

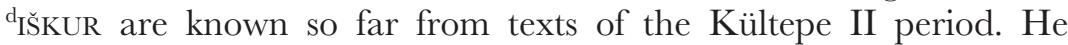
concludes that the Anatolian storm-god of Kaneš was no other than the god Nipas, whose name he tentatively connects with the HittiteLuwian word for "sky, heaven" nepiš- resp. tappaš- (tipas-). The local storm-god of Kaneš-Neša, one of the most important early Hittite settlements in Anatolia, would have been the deified sky, just as the storm-god is frequently called "storm-god of heaven" from the Old Hittite period onwards. He would have been superseded by Tarhun(t) after the level II period. ${ }^{48}$ Though this hypothesis may look attractive at first sight, there are a number of important objections to be raised. First of all, there are attestations for the local storm-god written ${ }^{\mathrm{d}}$ ǏKKUR in Kültepe II texts. There can be little doubt that the fragmentary passage TC 3, 191 obv. 11f. is to be restored PN [GUDU 4 ] $\check{s} a{ }^{\mathrm{d}}$ ISKKUR, and the name of the priest is most likely Anatolian, certainly not Assyrian; ${ }^{49}$ two more attestations for

45 See M. Popko, Religions of Asia Minor, Warsaw 1995, 73, for a different opinion see O. Carruba, Beiträge zum Palaischen, PIHANS 31, Leiden 1972, 9.

46 Thus N. Oettinger, "Hethitisch -ima- oder: Wie ein Suffix affektiv werden kann", in: Akten des IV. Internationalen Kongresses für Hethitologie, ed. G. Wilhelm, StBoT 45, Wiesbaden 2001, 474.

${ }^{47}$ See the list in Wettergottgestalten, 243 to which now two references in kt 99/k 138A can be added (cf. G. Kryszat, "Herrscher, Herrschaft und Kulttradition in Anatolien nach den Quellen aus den altassyrischen Handelskolonien-Teil 2: Götter, Priester und Feste Altanatoliens", AoF 33 [2006] 107).

48 See Kryszat, AoF 33 (2006) 106f., 113f., 121.

49 Cf. Wettergottgestalten, 243. Kryszat, AoF 33 (2006) 106 mentions the text but deems the restoration to be too uncertain for any conclusions; in my view there 
priests of the storm-god are known from level II texts, but in both cases it seems likely that they were serving at the Adad temple in Aššur. ${ }^{50}$ More importantly, the temple of the storm-god (É ${ }^{\text {dIŠKUR }) ~}$ is mentioned in VS 26, 146 as the place where the 'Head of the Storehouses', an official of the Anatolian palace hierarchy, received a garment; it appears very unlikely that this sanctuary should be sought in Aššur or that a-so far otherwise not attested-Assyrian Adad shrine within the kārum is meant. ${ }^{51}$ Furthermore, Hittite nepišis a neuter noun; it would be surprising to find a neuter noun without any additional morphemes as name of one of the principal gods of Kaneš. If Nipas was a Hittite word and the name of one of the most important Hittite gods at the same time, it would also be unexpected that the name does not survive at all after the Old Assyrian period. Finally, the hypothesis has to assume that in the divine Name Nipas the suffix -os/-es- developed as in Luwian (tappaś-), while the root itself preserved initial $n$ - as in Hittite (nepi $\left.\check{s}^{-}\right) .{ }^{52}$

\subsection{Position in the Pantheon}

Through all periods of Hittite history the storm-god, whose main manifestation is also called "storm-god of heaven", stands at the top of the imperial pantheon as well as numerous local panthea together with the sun-goddess, his wife. The highest divine couple, storm-god (Taru, Tarhun[t]) and sun-goddess (Eštan, Ištanu), presumably also embodied the cosmic pair heaven and earth, as the sun-goddess can be called "mother of the earth" (perhaps also "mother earth"). ${ }^{53}$ Presumably it is only from the Old Hittite period that this is connected with the idea of a night manifestation of the sun-goddess, as opposed to the male sun-god of heaven. The actual consort of the storm-god was particularly considered from the Old

can be little doubt that GUDU $_{4}$ (or possibly another priestly title) has to be restored. Kryszat reads the name in question $W a-a r-G A-t i-e[l]$, and this may be better than the Wa-ar-kà-l[i] (comparable to Hittite warkant- "fat") proposed in Wettergottgestalten. Nevertheless, the name is certainly not Assyrian, but most likely Anatolian (cf. already E. Laroche, Les noms des Hittites, Études linguistiques 4, Paris 1966, 204).

50 For the attestations see supra, fn. 46.

${ }^{51}$ See Wettergottgestalten, 242f., cf. also K.R. Veenhof, "Old Assyrian isurtum, Akkadian eșerum and Hittite GIŠ.HUR", in: Studio historiae ardens. Studies Ph.H.F. Houwink ten Cate, ed. Th.P.J. van den Hout-J. de Roos, PIHANS 74, Leiden, 324.

52 For the etymology and stem formation of nepiš- see E. Rieken, Untersuchungen zur nominalen Stammbildung des Hethitischen, StBoT 44, Wiesbaden 1999, 187-188.

53 See Klinger, StBoT 37, 145-147. 
Hittite period to be the sun-goddess as worshipped in Arinna (Ištanu of Arinna, Arinittiya, Ariniddu,${ }^{54}$ who is certainly typologically close to the sun-goddess of the earth in terms of the dichotomy sun-god of heaven - sun-goddess of the earth, without actually being a goddess of the underworld. In contrast to Šāla beside Adad or Hēbat beside Teššb, the consort of the storm-god was not an unimportant deity, whose typical functions were exhausted with that of a consort; rather she was equal in rank to her partner and was the most important goddess of the pantheon with her own circle of deities and court.

Storm-god and sun-goddess together hand over the country to the Hittite king to administer; he calls them mother and father within the framework of this concept. ${ }^{55}$ The Hittite king himself was considered to be sun-god of the country at the same time and wore the garb of the sun-god of heaven, with whom he shared various functions. The sun-god of heaven himself was considered the son of the storm-god (later he received a different filiation due to Hurrian and Babylonian influence), but occupied in particular contexts a similarly high or even higher rank to the storm-god, particularly in lists of oath-gods. ${ }^{56}$

The cult of the storm-god was wide-spread, some 150 cult places are attested in the written sources. The local manifestations of the storm-god were mostly considered to be sons of the storm-god of heaven; the two most important local manifestations, the storm-god of Nerik and the storm-god of Ziplanda, were identified with each other in the Empire Period. The same embedding in the pantheon as son-gods was also then applied to some of the many aspectually differentiated manifestations of the storm-god; typical examples of such aspectually differentiated manifestations of the storm-god include the storm-god "of thunder", "of the meadow", "of the (the king's) person", "of the market", "of the army", "of the oath" etc.

${ }^{54}$ For the name of the sun-goddess of Arinna cf. Klinger, StBoT 37, 144, J.D. Hawkins, The Hieroglyphic Inscription of the Sacred Pool Complex at Hattusa (Südburg), StBoT Beiheft 3, Wiesbaden 1995, 32.

55 As attested in the well-known texts KUB 29, 1-3 and IBoT 1, 30 //, see most recently Klinger, StBoT 37, 136f. with further literature.

56 Cf. Schwemer, "Das hethitische Reichspantheon. Überlegungen zu Struktur und Genese", in: Götterbilder - Gottesbilder-Weltbilder. Polytheismus und Monotheismus in der Welt der Antike. vol. I: Ägypten, Mesopotamien, Kleinasien, Syrien, Palästina, ed. R.G. Kratz-H. Spieckermann, FAT 2/17, Tübingen 2006, 241-265, esp. 243-253 with further literature. 
Some of the storm-god's epithets were established as gods in their own right. ${ }^{57}$

The best known actual son of the storm-god was Telipinu, who himself had characteristics of a storm-god but was seen as an independent deity and was never written with the logograms for the storm-god (see 9.3). The figure of Telipinu, nevertheless, served presumably as the model for the categorisation of the other stormgods as son-gods. The daughter of the storm-god was considered to be the Hattic goddess Inar, who plays an important role in the Illuyanka myth. The likewise Hattic goddess Zintuhi was regarded as the grand-daughter of the sun-goddess and the storm-god. The father and grand-father of the storm-god are attested in the myth of the lost storm-god. Within a single context, however, we find no more than three generations at the same time.

From the Middle Hittite period Syro-Hurrian influences had increasing influence upon the religion practised by the Hittite royal family. Tarhun $(\mathrm{t})$ was identified with the Hurrian storm-god and king of the gods, Teššub, Hurrian Teššub myths, particularly the Kumarbi-cycle, were transferred to Tarhun( $\mathrm{t})$ as part of the process of translation into Hittite. Particularly Teššub of Halab occupied an important position in the cult of Hattuša (see supra, 4.4, 5.4). The divine circle of Teššub with Hazzi and Nanni and Šēri and Hurri was integrated permanently into the Hittite imperial pantheon. The sun-goddess of Arinna was identified with Hèbat, consort of Teššub, in some contexts, though in lists of oath-deities and other texts not belonging to the Hurro-Hittite stratum Hēebat never takes the place of the sun-goddess of Arinna, but is listed separately, often with the other Syro-Hurrian gods of Teššub's circle or with the storm-god of Halab.

\subsection{Modus Operandi in Mythology and Ritual}

The storm-god had power over storms, tempests and rain, as the highest god of the pantheon he was also in a special way lord and protector of the land. He was seen as a god of heaven and was frequently called "storm-god of heaven" from the Old Hittite period on. The god was also often represented theriomorphically as a bull down to the late period, even if an anthropomorphic conception was naturally assumed for religious literature; in anthropomorphic

57 E.g. Pihaimmi and Pihammi, see CHD P 253. 
representation the bull still remained his symbolic animal. Thus, it was presumably not only under the influence of the divine circle of Hurrian Teššub that a pair of bulls pulled the chariot of the storm-god; there was also a competing (Luwian) tradition in which horses pulled the chariot of the storm-god. ${ }^{58}$

The violence of the thunderstorm meant danger for humans, animals and crops. In particular thunder during a storm was seen as an expression of the god's wrath (as in Mesopotamia), which could then be appeased in special tempest rituals, including the ritual during which the myth of "The Moon-God that Fell from Heaven" in fear during a thunderstorm was recited. ${ }^{59}$ Muršili's 'aphasia' was interpreted as a consequence of the fear brought upon Muršili II by the storm-god through thunder, the illness of Uhhaziti of Arzawa was caused by the sighting of the storm-god's kalmišana-, his thunderbolt or possibly an even more violent manifestation of the god's might (a meteor?). ${ }^{60}$

As god of rain, the storm-god was at the same time responsible for the maintenance and welfare of the country. Thus within the great AN.DAH.ŠUM-festival in the spring, a rain-ritual was celebrated for the storm-god in Ankuwa. ${ }^{61}$ The Anatolian myths of the vanished god type, which were primarily, but not exclusively, connected with Telipinu and storm-gods, describe the consequences of the absence of the angry storm-god as drought, famine and the end of all fertility. The return and appeasement of the vanished god brings back abundance, and the storm-god (or Telipinu) reassumes his function as patron of the king. ${ }^{62}$

58 See M. Hutter, "Aspects of Luwian Religion", in: The Luwians, ed. H.C. Melchert, HdO 1/68, Leiden-Boston 2003, 222 with the relevant attestations.

59 For this text see H.A. Hoffner Jr., Hittite Myths, WAW 2, Atlanta ${ }^{2} 1998,34-$ 36 text 12; cf. also E. Neu, Ein althethitisches Gewitterritual, StBoT 12, Wiesbaden 1970 and G. Wilhelm, "Zur Ritual- und Redaktionsgeschichte des althethitischen Gewitterrituals GTH 631.1", in: Atti del II congresso internazionale di Hittitologia, ed. O. Carruba e.a., StudMed 9, Pavia 1995, 381-388 with references to other rituals of the same type (p. 388).

60 See N. Oettinger, "Hethitisch -ima- oder: Wie ein Suffix affektiv werden kann", in: Akten des IV. Internationalen Kongresses für Hethitologie, ed. G. Wilhelm, StBoT 45, Wiesbaden 2001, 473f. with the relevant references.

${ }_{61}$ For the AN.DAH.ŠUm-festival see V. Haas, Geschichte der hethitischen Religion, HdO I/15, Leiden 1994, 772-826, cf. also Schwemer, "Von Tahurpa nach Hattuša: Überlegungen zu den ersten Tagen des AN.DAH.ŠUm-Festes", in: Offizielle Religion, lokale Kulte und individuelle Religiosität, ed. M. Hutter-S. Hutter-Braunsar, AOAT 318, Münster 2004, 395-412.

${ }^{62}$ For the myths of disappearing gods see H.A. Hoffner Jr., Hittite Myths, WAW 2, Atlanta ${ }^{2}$ 1998, 14-34, 37f.; cf. also M. Mazoyer, Télipinu, le dieu au marécage, Paris 2003. 
The Illuyanka-myth, which was embedded in the purulli springfestival, interpreted the flourishing of vegetation through the early year's rainfalls as the liberation of the storm-god from a temporary imprisonment (or physical powerlessness in a second version of the myth): The storm-god is defeated by the snake-dragon Illuyanka in battle and imprisoned (or robbed of his heart and eyes). His daughter, Inar, succeeds in liberating her father, but only with the help of a human, a man called Hupašiya; the liberated storm-god then kills Illuyanka (first version). Also in the second version it is only with the help of humans that the storm-god gets back his heart and eyes. He sires a son with the daughter of a poor man; that son is then married off to a daughter of Illuyanka. Being the son of a poor woman, the son enters the house of his wife and asks for the heart and eyes of his father as a compensation to be given to his father's house. Thus the storm-god regains his old power and kills Illuyanka with its family including his son. The involvement of humans in both versions of the myth probably refers to the king's role as the storm-god's administrator and helper on earth. Unfortunately, the passages of the text referring to the king himself are fragmentary and still not well understood. Anyhow, by performing the ritual associated with the myth the land flourished under the patronage of the storm-god. ${ }^{63}$

\section{The Victory of the Storm-God over the Sea}

From a short passage in a letter of the correspondence between Mari and Aleppo from the Old Babylonian period it is apparent that a myth was associated with Haddu of Halab according to which this god achieved the kingship among the gods by means of a victory over the sea-goddess, Têmtum. ${ }^{64}$ This myth of divine kingship was obviously an essential element of the Aleppine royal ideology; the weapons of Haddu played an important role in the installation of a new king (cf. supra, 4.3.2, 4.4).

63 For an edition and discussion of the myth see G. Beckman, "The Anatolian Myth of Illuyanka", FANES 14 (1982) 11-25, cf. also idem, "The Storm-God and the Serpent", in: Context of Scripture I, ed. W.W. Hallo, Leiden 1997, 150-151 and H.A. Hoffner, "A Brief Commentary on the Hittite Illuyanka Myth (CTH 321)", Studies R.D. Biggs, Chicago 2007, 119-40.

64 See Wettergottgestalten, 226-227, 228-237 on A. 1968 and related texts with further bibliography. 
The mythologeme of the victory of the king of the gods and storm-god over the sea was then associated with various storm-gods in Syria, Upper Mesopotamia and beyond:

Balu of Ugarit defeats the sea-god and temporary king of the gods, Yammu, in his struggle for the kingship among the gods. In Ugarit, too, the myths about the kingship among the gods had great significance for the royal ideology of the ruling class (cf. supra, 6.2.2). ${ }^{65}$

Various Hittite mythological and ritual fragments which belong to the Syro-Hurrian strand of tradition (mainly KUB 33, 89+, KUB 33, 108, CTH 785) show that a similar myth was told of Hurrian Teššub, which was then transferred, at least superficially, to Hittite Tarhun(t). ${ }^{66}$ The motif of the enmity between the sea and the stormgod was also not alien to the myths of the Kumarbi-cycle. The monster Hedammu lives in the sea, ${ }^{67}$ and the stone giant Ullikummi stands in the sea too. If $K B$ o 26, 105 actually was the last song of the cycle and can be restored in line with the Seth myth attested in the Egyptian 'Astarte Papyrus', the conflict between Kumarbi and the storm-god culminated in a fight between the latter and the sea-god, in which the storm-god finally secured the honour of kingship for himself (cf. supra, 5.4). The Astarte papyrus, as well as certain other relevant texts, shows that the material of the myths was adapted in Egypt, too, and associated with Seth, who stood for the Near Eastern storm-god. ${ }^{68}$

In the second version of the ancient Anatolian Illuyanka-myth (see 7.3) the battle between the storm-god and the snake-dragon

65 See Wettergottgestalten, 229ff., 534-541, esp. 534f., cf. also Green, Storm-God, 178-190.

66 See Wettergottgestalten, 232-234, 451f. with fn. 3736; the storm-god's victory over the sea is mentioned explicitly in KUB 33, 108 obv. II $17^{\prime}$ and $K U B$ 44, 7 obv. I 11'f. // KBo 42, 2 obv. I 15f. (CTH 785), perhaps also in KUB 33, 89+

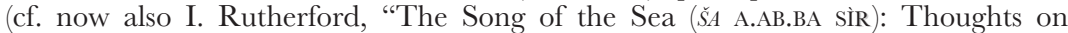
KUB 45.63", in: Akten des IV. Internationalen Kongresses für Hethitologie Würzburg, 4.-8. Oktober 1999, StBoT 45, Wiesbaden 2001, 598-609).

67 Note within this context that B. André-Salvin-M. Salvini, "Un nouveau vocabulaire trilingue sumérien-akkadien-hourrite de Ras Shamra", SCCNH 9 (1998) 9f. and M. Dijkstra, "The Myth of apš "the (Sea)dragon" in the Hurrian Tradition", UF 37 (2005) 315-328 show convincingly that Hurrian apši, which is equated with Akkadian șeru "snake, serpent" and Ugaritic tunnanu "serpent, sea monster", is used as a designation of Hedammu in Hurrian context. Tunnanu is one of the sea monsters defeated by Ugaritic Ba'lu (see Wettergottgestalten, 232 fn. 1605-06 with literature).

68 See Wettergottgestalten, 446-454; for more Egyptian parallels see now Th. Schneider, "Texte über den syrischen Wettergott aus Ägypten”, UF 35 (2003) 605-627. 
Illuyanka took place by or in the sea. This may be a case of a motif borrowed from North-Syrian traditions, but this is not necessarily true; one should bear in mind that the sea-god also appears in the myth of 'Telipinu and the Daughter of the Sea' as a hostile power to the gods of heaven, and this myth is entirely free of NorthSyrian influences. ${ }^{69}$

Also the sovereignty of Old Testament Yahwe was associated with a victory over the forces of chaos residing in the sea, and, at the latest, in the stories of the conflict between Zeus and Typhon motifs from the second version of the Anatolian Illuyanka-myth occur together with North-Syrian traditions. ${ }^{70}$

The mythologeme of the victory of the storm-god over the sea is certainly old; whether it is actually attested in incantations from pre-Sargonic Ebla remains questionable. ${ }^{71}$ The motif is attested early in connection with different gods of Babylonia. It was already associated with the god Tišpak in the Akkad period in the Diyala area and tied there to the chaos-fighting motif of Ninurta-mythology (cf. the later Labbu myth). In the great Ninurta myths, however, the sea does not play a role as the opponent of the gods. But also Ninurta receives epithets that praise him as victor over monsters living in the sea like the kusarikku. For Nergal, who shares characteristics with Ninurta as a war-god, we have a myth about his struggle against a sea-monster from the Neo-Assyrian period. ${ }^{72}$

The motif of the struggle against the powers of chaos in the mythology of Ninurta then formed an essential part of Marduk theology. While only later attested explicitly, it already was taking shape in the Old Babylonian period as a way of justifying the

69 See Wettergottgestalten, 234-236.

70 See Wettergottgestalten, 236f.; for Yahwe's being described in the terms of a storm-god cf. now also H.-P. Müller, "Zur Grammatik und zum religionsgeschichtlichen Hintergrund von Ps 68,5", ZAW 117 (2005) 206-216.

${ }^{71}$ Thus Wettergottgestalten, 116-119, 228; for a different view see P. Fronzaroli's contributions on the Ebla incantations, most recently "The Hail Incantation (ARET 5, 4)", in: Fs. B. Kienast, ed. G. Selz, AOAT 274, Münster 2003, 89-107.

72 See Wettergottgestalten, 229-232, 174, 183-188; for the Labbu myth and related texts cf. also P.-A. Beaulieu, "The Babylonian Man in the Moon", fCS 51 (1999) 91-99; for the motif of the young king of the gods as victor over the forces of chaos in Babylonian theology and royal ideology, see also S.M. Maul, "Der Sieg über die Mächte des Bösen. Götterkampf, Triumphrituale und Torarchitektur in Assyrien", in: Gegenwelten zu den Kulturen Griechenlands und Roms in der Antike, ed. T. Hölscher, Leipzig 2000, 19-46, and, especially with respect to Ninurta, A. Annus, The God Ninurta in the Mythology and Royal Ideology of Ancient Mesopotamia, SAAS 14, Helsinki 2002, 109ff., 171ff. 
elevation of Marduk, a local god of Babylon, to the king of the gods. In Enumma eliš the opponent of Marduk in the battle that guarantees him kingship over the gods is not one of the traditional opponents of Ninurta, but Tiāmat, the primeval ocean. This is obviously the same or a very similar narrative motif as attested for Old Babylonian Haddu of Aleppo in his victory over Têmtum (a variant form of Tiāmat). It is therefore not unlikely that the Aleppine storm-god theology and royal ideology had some influence on the Marduk-theology that had recently been formed in Babylon; close relations between the two royal houses are well attested. The fact that similar motifs had already been associated with other gods in Babylonia should have made the reception easier. The mythologeme of the victory of the new king of the gods over the chaotic sea probably originated in the eastern Mediterranean; but it spread so early that the individual lines of the tradition's history can no longer be traced. Consequently the concrete myths in which the basic motif occurs offer quite a heterogeneous picture. It should finally be noted that the association of the Tiāmat-myth even in Roman times with Palmyrene Bēl is not due to the survival of old Syrian and Upper Mesopotamian traditions, but is owed to Babylonian influence (Marduk-Bēl theology). ${ }^{73}$

\section{Further Gods with Storm-God Characteristics}

\subsection{The North-Babylonian and Assyrian Storm-God Wēr}

The god Wēr (variant form: Mēr), whose name was mostly written Bēr from the Middle Assyrian period, was a storm-god worshipped primarily in North Babylonia, on the Middle Euphrates and in Assyria. ${ }^{74}$ The divine name, which is always written syllabically and

73 See L. Dirven, "The Exaltation of Nabû. A Revision of the Relief Depicting a Battle against Tiamat from the Temple of Bel in Palmyra", WdO 28 (1997) 96116, Annus, The God Ninurta, 194.

${ }^{74}$ For W/Mēr, W/Mērtum and Iluwēr see Wettergottgestalten, 200-210, 32-33. Note that in Wettergottgestalten, 36 fn. 180 (contra S. Zawadski, Garments of the Gods, OBO 218, Fribourg - Göttingen 2006, 182f.) I did not argue for an original identity between Wēr and Immeriya nor do I think that Immeriya was a goddess identical with Immertu, and nowhere did I argue that there is any relation between Immertu and Adad. I do, however, still think that Immertu is likely to be a goddess because of the formation of the name and Immeriya might be the corresponding masculine form. The character of the god Immeriya is unknown, and before more evidence becomes available one cannot tell how significant the variant 
never with the Sumerogram dišKUR, can be securely attested from the Akkad period, though references outside personal names are so far only available from the Old Babylonian period onwards. It remains highly questionable whether a theophoric element attested in the Early Dynastic onomasticon as Meru (thus?) represents the later god W/Mēr. Linguistic affiliation and etymology have not yet been estabished with certainty. There is no evidence apart from sound that the name would go back to Akkadian *Wāiru (thus J.-M. Durand), and one would expect the uncontracted form to be preserved in Babylonia and Assyria if not on the Middle Euphrates. A connection with the place-name Mari (and Akkadian amurru, thus M. Bonechi) can be firmly excluded, and an original identity with the geographical name Uri-Warûm, which appears attractive in view of the important position Wēr held in that area, is not proveable either; the fact that the name of Wēr's wife was W/Mērtum (not *Wērītum or similar) also militates against this hypothesis. A Sumerian etymology (cf. IM-mer "north wind", mer and me-er-me-er "storm", Emesal me-er "wind", thus H. Schlobies and, more recently, A.R.W. Green) appears unlikely with regard to the origins and background of Wêr who is never equated by the Babylonian scholars with deified Mermer(i), an epithet attributed to Iškur-Adad, Ninurta, Mercury and Nabû. ${ }^{75}$ In the Old Babylonian period sources for the cult of Wēr come primarily from northern Babylonia and the Diyala region, but a few relevant personal names occur also in texts from the Babylonian south. From the Middle Babylonian period we have no further information on Wēr from Babylonia, but his cult thrived in Assyria, and was also known in Syria. Wēr is equated with IškurAdad in the god-lists, and from the Old Babylonian period the connection between Wēr and Adad is well attested outside the god-lists, too. Beside Wēr, the god-lists also equate Iluwēr with Adad, clearly a late extended form of the name meaning "the god Wēr" that follows a well-known pattern of formation for Babylonian divine names. This late form of the name is also attested in Aramaic inscriptions from Syrian Tell Afis. It remains unclear whether the writings ${ }^{\mathrm{d}} b_{e}$ er in the Neo-Assyrian period should partly be read il-be-er. The god Itūrmēr worshipped at Mari was a dynastic and ancestral god (Itūr-

\footnotetext{
${ }^{\mathrm{d} w e-e r} / / \mathrm{d}$ im-me-ri-ia in Šurpu II 181 really is (for Šurpu II 181 see now R. Borger, "ŠurpuII, III, IV und VIII in „Partitur"", in: Wisdom, Gods and Literature. Studies W.G. Lambert, ed. A.R. George-I.L. Finkel, Winona Lake 2000, 34).

75 For Mermer(i) see Wettergottgestalten, 58-59, cf. also 29-30.
} 
Mēr originally being a theophoric personal name "Mēr has turned [to me]") and has nothing to do with W/Mēr. ${ }^{76}$

\subsection{The Babylonian God of the Western People, Mardu-Amurru}

The god Amurru(m), Sumerian Mardu, was a Babylonian god who embodied the Western Lands (Akkadian amurrum "west") in the pantheon and particularly the nomads of the Western Lands, the Amorites, from a Babylonian perspective (amurrum also used as collective noun for "Western people", "Amorites"). ${ }^{77}$ In the Amorite cultural area itself his cult played no major role. ${ }^{78}$ Amurru, whose name also occurs in the extended form Ilamurrum in the Old Babylonian period, ${ }^{79}$ had among other features those of a storm-god:

76 Contra Green, Storm-God, 61-63, 87-88, who without any further explanation treats the names Ilumēr and Itūrmēr as simple (i.e. phonetic?) variants.

77 For Mardu-Amurru(m)'s character and his relationship to Adad see Wettergottgestalten, 198-200 with further literature (to which add: W.W. Hallo, "Two Letter-Prayers to Amurru", in: Boundaries of the Ancient Near Eastern World. Studies C.H. Gordon, ed. M. Lubetski e.a., JSOT Suppl. 273, Sheffield 1998, 397-410); cf. now also P.-A. Beaulieu, "The God Amurru as Emblem of Ethnic and Cultural Identity?", in: Ethnicity in Ancient Mesopotamia (CRRAI 48), ed. W. van Soldt e.a., PIHANS 102, Leiden 2005, 31-46.

${ }^{78}$ For A. 975 obv. 19, quoted in Wettergottgestalten, $198 \mathrm{fn}$. 1353, see now FM 8, text 38 .

${ }^{79}$ Cf. Wettergottgestalten, 32f. with fn. 160 on Ilamurrum and the similarly structured divine names $\mathrm{Il}(\mathrm{u})$ wēr, Ilmīšaru, Iltammeš, Ilteher, Ilulāya, Ilaba, Il(u)nergal (?) (cf. also W. Farber, "(W)ardat-lilî(m)", ZA 79 [1969] 17f. on possible IlumErra). Th. Richter, "Die Lesung des Götternamens AN.AN.MAR.TU", SCCNH 9 (1998) 135-137 argues that the logogram ${ }^{\mathrm{d}}$ DINGIR.MAR.DÚ should be interpreted rather as a genitive compound ("God of Amurru") than a juxtapposition, because the Hurrian translation of the logogram in the 13th cent. Hurro-Babylonian god-list from Emar apparently interprets the logogram as a genitive construction: ${ }^{\mathrm{d}} \boldsymbol{e}-n i-a-m u r-r[i-w e]$ (1. 175 according to Laroche, GLH, 82, who first proposed this restoration and indicates that traces of the $r[i$ are preserved). The directly preceding entry interprets ${ }^{\mathrm{d}}$ MAR.DÚ as ${ }^{\mathrm{d}} a-m u r-r u$-[he] (restoration Laroche, followed by Richter), i.e. "Amorite" (Amurr $\left.(i)={ }_{0}=h h e\right)$. This suggests that the author of the Emar god-list interpreted the Akkadian name of the god Amurru as Amurrû and probably associated it rather with the geographical name Amurru contemporary to him than with Mardu-Amurru as the deified "West(ern People)". Despite Richter's remarks on the general reliability of the Hurrian interpretations and translations of the list (p. 137), it seems therefore likely that also the following line 175 offers an anachronistic interpretation of dDINGIR.MAR.DÚ as "god of the land of Amurru". Note that comparison with CAT 1.125 (Ugaritica 5, 504f. text 2), a Hurrian ritual text in alphabetic script from Ugarit, if relevant at all supports this interpretation. The text has $i[n]$ amrw in obv. 6, which, according to Richter (and following him, P.-A., Beaulieu, CRRAI 48, 31 fn. 4), is to be understood not as "god of (the land) Amurru" (thus Laroche in Ugaritica 5), but as a divine name of its own, namely the same "Ilamurrim" that would be represented by "DINGIR.MAR.Dú in Old 
He bore the epithet Rammānu(m) "Thunderer", which then became a god's name in its own right, without actually being separated from Amurru. In literary texts, Mardu-Amurru is described as a lightning-flashing, warlike tempest-god; in the Middle Assyrian godlist KAV 64 the lightning-god Nimgir is ascribed to his divine circle. In depictions on seals from the Old Babylonian period he is often found together with Adad. The lightning symbol stands for him as well as Adad, but Amurru's special symbol is the nomad's crook, which is never associated with Adad. Amurru is never written with the logogram ${ }^{d}$ IŠKUR and also never equated with IškurAdad in the god-lists known so far. At least Hadad of Damascus in the 1st mill. had the same epithet Rammān(u), and this might have been the case for other Hadad-manifestations, as Rammān is fairly widespread in the Aramaic onomasticon; particularly in Babylonia the god Amurru was probably understood by it, however, also during the 1st mill. Anyhow, a direct connection between Rammānu as an epithet of Amurru and as an epithet of Aramaean Hadad cannot be established on the basis of the current state of the sources: the god Rammānu (logographically ${ }^{\mathrm{d}} \mathrm{KUR}$, which is perhaps also used for Amurru himself) is never written with the logogram dišKUR or associated with Adad in the Assyro-Babylonian god-lists. ${ }^{80}$ One can only speculate on the question of whether the circumstance that Mardu-Amurru had the characteristics of a stormgod was originally connected with the fact that the storm-god Haddu was the most prominent god of the Amorite cultural area beside the moon-god. But it cannot be ruled out that the most important Amorite god served in some respect as model for the conceptualisation of a god embodying the Amorites in the Babylonian pantheon. But

Babylonian sources. But the immediate context in the ritual text militates against this interpretation: $i[n]$ amrw is referred to within the sequence in aldyg $i[n]$ amrw in ugrtw, and neither a "God of Alašiya" nor a "God of Ugarit" are known from other sources. Clearly, all three genitives have to be interpreted as actual geographical names and in is therefore probably plural (enna): "the gods of the land of Alašiya, the gods of the land of Amurru, the gods of the land of Ugarit" (cf. for this interpretation also M. Dietrich-O. Loretz, "Ein hurritisches Totenritual für 'Ammištamru III. (KTU 1.125)", in: Ana šadî Labnāni lū allik. Fs. W. Röllig, ed. B. Pongratz-Leisten e.a., AOAT 247, Münster 1997, 79-89). It goes without saying that the Amurru referred to here has nothing to do with the Amorites or the god Amurrum of the Old Babylonian period, but refers to the land of Amurru to the south of Ugarit.

${ }^{80}$ For Rammānu see the references JANER 7/2, 160 fn. 113. 
Mardu-Amurru's profile comprises many other features which are alien to the storm-god Haddu or Adad, in particular that of the non-urban nomad.

\subsection{The Anatolian Vegetation- and Storm-God Telipinu}

The Hattic-Hittite god Telipinu was the son of the storm-god TaruTarhun(t) (see 7.2, 7.3 with further references). His name is never written with the logograms for the storm-god, nor is he ever identified with any of the numerous manifestations of the storm-god considered to be sons of the storm-god (of heaven). He only occupied a secondary position in the Hittite imperial pantheon, as opposed to the storm-god and didn't play any particular role in the Hittite royal ideology according to the Annals and those texts which are particularly concerned with the relationship of the Hittite king to the storm-god and the sun-goddess. But it is especially with Telipinu, too, that the myth-type of the vanished god was associated. In these myths Telipinu has the typical characteristics of a storm-god: his disappearance brings drought and suffocates all life; he flashes with lightning and thunders in his anger; his appeasement and return brings the land of Hatti back into a state of order, balance and abundance. Within the myth it is Telipinu who appears as the special protector of the king. The purulli-festival in the spring was also celebrated locally for Telipinu, and the Telipinu myth may have served as the festival's myth in these places. In the myth of "Telipinu and the Daughter of the Sea", Telipinu appears as the son of the storm-god who marries the daughter of the sea-god to thereby release the sun-god from the power of the sea-god. Telipinu's original connection to the family of the storm-god as an independent deity with the characteristics of a storm-god in the wake of his father, but primarily representing a son-deity, prevented the identification of Telipinu himself with other manifestations of the storm-god. Nevertheless, the systematisation of local manifestations of the storm-god as sons of the storm-god of heaven will certainly have followed the pattern set by the figure of Telipinu.

\section{A Few Remarks on Iconography}

There is no comprehensive study of the iconography of the various storm-gods with reliable illustrations and up-to-date information; the following remarks can therefore only have a provisional 
character. ${ }^{81}$ The earliest pictorial representations of the Babylonian storm-god, in all likelyhood Iškur-Adad, ${ }^{82}$ are to be found in the glyptics of the Old Akkadian period. As a rule the god stands on a chariot with two axles that is pulled by a water(?)-spitting liondragon. He also swings the whip symbolising both thunder and lightning, the flick and crack of the whip. The winged lion-dragon is to be identified with the storm-monsters who, according to the

${ }^{81}$ For various remarks on the storm-god's iconography which cover most of the following comments see Wettergottgestalten, 124ff., 174 with fn. 1231, 196, 199, 227, 228f., 425 with fn. 3521, 480f. with fn. 3923, 484 with fn. 3960, 615 as well as fn. 3035, 3418, 4097, 5011, 5081 with further references. Green, Storm-God, 13-34, 103-127, 154-165 tries to give a more systematic summary without taking into account, however, more recent studies on the subject; the figures in the book often do not meet the standards of the field, and, as with the texts, reading and interpretation of the evidence heavily relies on secondary literature. Important contributions to the iconography of the storm-gods include: A. Vanel, L'iconographie du dieu de l'orage dans le Proche-Orient ancien jusqu'au VII siècle avant F.-C., Cahiers de la Revue Biblique 3, Paris 1964; A. Abou-Assaf, "Die Ikonographie des altbabylonischen Wettergottes", BaM 14 (1983) 43-66; Natural Phenomena. Their Meaning, Depiction and Description in the Ancient Near East, ed. D.J.W. Meijer, Amsterdam e.a. 1992 (various articles); E.A. Braun-Holzinger, "Altbabylonische Götter und ihre Symbole. Benennung mit Hilfe der Siegellegenden", BaM 27 (1996) 235-359; E. Klengel-Brandt, "Eine ungewöhnliche Wettergottdarstellung", AoF 29 (2002) 288295; D. Beyer, Emar IV: Les sceaux, OBO SA 20, Fribourg-Göttingen 2001, 299306; K. Jakubiak, "New Aspects of God Teisheba's Iconography, AoF 31 (2004) 87-100; G. Bunnens in: G. Bunnens-J. D. Hawkins-I. Leirens, Tell Ahmar II. A New Luwian Stele and the Cult of the Storm-God at Til Barsib-Masuwari, Leuven 2006, 33135; idem, "The Storm-God in Northern Syria and Southern Anatolia from Hadad of Aleppo to Jupiter Dolichenus", in: Offizielle Religion, lokale Kulte und individuelle Religiosität, ed. M. Hutter -S. Hutter-Braunsar, AOAT 318, Münster 2004, 57-81.

82 Unlike in later periods the representations of gods on Akkadian seals are not identified by name in accompanying seal inscriptions. Following H. Frankfort, R.M. Boehmer identified a number of iconographical types on Akkadian seals as storm-gods ("Wettergottheiten", "Donnergott", see Die Entwicklung der Glyptik während der Akkad-Zeit, UAVA 4, Berlin 1965, 62ff.) without committing himself to a specific name. Taking into account the evidence from the texts and the later development of the iconographical motifs associated with Iškur-Adad it appears most likely that the storm-god on the Akkadian seals is no other than Iškur-Adad. It is true that a specific type of lion-dragon is associated with Ninurta too, and that Ninurta exhibits traits of a storm-god within the context of his role as warlike victor over the powers of chaos. In the Neo-Assyrian period Ninurta can be depicted chasing the Anzû-bird with lightning ('thunderbolts'), and these scenes are sometimes misinterpreted as representations of Adad (cf. Wettergottgestalten, $174 \mathrm{fn} .1231$ with references, cf. now also, especially for the attestations of the motif on seals D. Collon, "The Iconography of Ninurta", in: The Iconography of Cylinder Seals, ed. P. Taylor, Warburg Institute Colloquia 9, London-Turin 2006, 101, 105f.). Nevertheless, it appears unlikely that the storm-god depicted on Akkadian (or later on Mittani-period) cylinder seals is meant to represent Ningirsu-Ninurta (differently D. Collon, art. cit., 101f., 107f.). 
texts, pull the chariot of Iškur-Adad, when the god storms and rumbles over the sky. The storm-god can be accompanied by a sometimes naked, sometimes clothed goddess who is surrounded by rain or holding rain-water (sometimes also lightning?) in her hands; both the storm-god and the goddess are also shown standing on liondragons. The naked rain-goddess, who also appears in the glyptic of the 2nd mill., should probably be identified with Medimša-S̄āla. The same iconographic motif is also attested in the Syrian and Upper Mesopotamian area, but here the female escort of the stormgod cannot be simply identified with Šāla. One should always bear in mind that iconographic motifs can be borrowed and reinterpreted without necessarily adopting the concept that was associated with them originally. The goddess sometimes stands in a (winged) 'door'-arch, which perhaps represents the same motif as the 'winged temple on a bull' in Old Akkadian glyptic and presumably symbolises the rainbow, which as so many phenomena and creatures of the sky is depicted in Mesopotamian art as winged. ${ }^{83}$ Seals of the Akkad-period showing the storm-god, or a god associated with him, as a bull-killer attest to the existence of a myth unknown from the texts. Otherwise in Babylonia the bull does not appear as an animal accompanying the storm-god before the Ur III period (but cf. the following paragraph for a rare exception).

From the second half of the Ur III-period it can be observed that the bull supersedes the previously pre-dominant lion-dragon in the figurative inventory of glyptic art as the symbolic creature of the storm-god, admittedly without replacing him completely; until the late period representations with bull and lion-dragon at the same time are to be found. Usually the god stands on the bull, or is about to mount it, holding the lightning symbol and often the bull's reins as well. A frequent variant shows the god beside the bull, which carries the lightning symbol on its back. The motif of the storm-god riding on a chariot drawn by a mythic animal symbolising (aspects of) the storm is not attested anymore in the Ur III and Old Babylonian periods. However, even in depictions of the Old Akkadian period, the chariot of the storm-god is not exclusively pulled

${ }^{83}$ See Wettergottgestalten, 125 with reference to M. van Loon's important articles "The Naked Rain Goddess", in: Resurrecting the Past. Studies A. Bounni, ed. P. Matthiae e.a., Leiden 1990, 363-378, and "The Rainbow in Ancient West Asian Iconography", in: Natural Phenomena. Their Meaning, Depiction and Description in the Ancient Near East, ed. D.J.W. Meijer, Amsterdam e.a. 1992, 149-168. 
by the lion-dragon, but in at least one case also by a bull, so that one can assume that the bull (or bulls) took over also this role in 2nd mill. Mesopotamian art; the motif is of course well-attested for 2nd and 1st mill. Syria and Anatolia both textually and iconographically. Likewise, in the first half of the 2nd mill., the motif of the storm-god leading a bull or a yoke of bulls by a bridle became established in Old Syrian glyptical art. Finally the Kültepeseals also show two types of storm-gods with reins, who, however, stand on the bull or are mounting it. At the same time this group of seals exhibits representations of the storm-god standing on the lion-dragon in traditional Babylonian fashion and of a completely theriomorphically depicted bull-god. The latter occurs nowhere else, is of Anatolian origin and must be identified with TaruTarhun(t), who could still be represented in bull form in the Hittite period.

The use of the wild bull as symbolic animal of the god of storm and tempest thus does not originate in the Sumerian tradition, and while it appears now and then in the Sargonic period in Babylonia, it becomes predominant only in the era of the Amorite dynasties of the Old Babylonian period. The fact that we know of no older instances of this motif from North Syria and Upper Mesopotamia too is probably due to two factors: on the one hand the thematic inventory of older Syrian glyptic art, from which depictions of gods, as known from the seals of the Old Akkadian period, are completely absent; on the other hand our still very incomplete knowledge of the iconography of 3rd mill. Syrian art on the whole. The central Anatolian bull- and storm-god should be kept separate, at least in the historical periods, from this North-Syrian bull symbolism, which was probably associated with Hadda. A combination of these two concepts can only be observed in the pictorial programme of the Kültepe-seals.

Prehistoric depictions and figurines of bulls, of anthropomorphic figures on bulls, bucrania and bull-horn installations from the Anatolian, Syrian and Mesopotamian area should not be associated too quickly with the storm-god iconography of the historical periods. ${ }^{84}$ They

${ }^{84}$ See Wettergottgestalten, 124-127. The statement that the figurine of a bullriding man from 6th mill. Çatal Hüyük may be the earliest anthropomorphous representation of the storm-god does not become any more meaningful by its regular repetition (cf. most recently M. Herles, Götterdarstellungen Mesopotamiens in der 2. Hälfte des 2. Jahrtausends v. Chr., AOAT 329, Münster 2006, 263). In a number of 
need interpretation firstly within their own iconographic context. Also one should bear in mind that the wild bull is not exclusively the symbol of the storm-god in the historical periods, either: all deities are characterised by bull-horns in ancient Near Eastern iconography; additionally, the wild bull is, like the lion, a symbolic animal of kingship and associated with different deities within this context. ${ }^{85}$

Bull and various lightning symbols remain through all historical periods the characteristic attributes of the storm-god. It is not certain that the bucranion is a symbol of the storm-god, the TONITRus sign of the Hieroglyphic Luwian script could, however, represent a stylised pair of bull-horns. ${ }^{86}$ The anthropomorphic depictions of the storm-god vary considerably from region to region and from period to period, and would need individual presentation far beyond the scope of the present summary. Different manners of depiction can be be ascribed to particular storm-gods, as long as the iconographic conventions follow the same linguistic-cultural borders as the texts. As G. Bunnens has shown for the representations of the storm-god of Aleppo in late 2nd and early 1st mill. art, certain iconographic conventions can be specific for local manifestations of the god, in the case of the storm-god of Aleppo even across linguistic borders. ${ }^{87} \mathrm{~A}$ general rule of thumb could be that in those

contributions J. Cauvin has drawn attention to the fact that from the 8th mill., and especially with the beginning of rainfall agriculture in Syria and Anatolia, bull and woman (usually in form of figurines) emerge as prominent religious symbols (see e.g. The Birth of the Gods and the Origins of Agriculture, Cambridge 2000, 123-125). While the wild bull may have been associated - among other things - with rain and thunderstorm already in the Neolithic period and the fact that storm-gods in Anatolia, Syria and Upper Mesopotamia during the historical periods are associated primarily with the bull may stand in some sort of continuity to the prehistoric religious symbols, the overall assemblage of religious symbols from the Neolithic periods is so different from the iconographic conventions of the later ancient Near Eastern cultures that an isolated identification of a specific (type of) god with an iconographic motif attested at least two millennia earlier contributes little to a better understanding of both phenomena.

85 On the latter point see Ch. Watanabe, Animal Symbolism in Mesopotamia. A Contextual Approach, WOO 1, Wien 2002.

${ }^{86}$ See U. Calmeyer-Seidl, "W", in: Studien zur Altertumskunde Kleinasiens. Fs. K. Bittel, ed. R.M. Boehmer-H. Hauptmann, Mainz 1983, 151-154, and J.D. Hawkins, "What Does the Hittite Storm-God Hold?", in: Natural Phenomena. Their Meaning, Depiction and Description in the Ancient Near East, ed. D.J.W. Meijer, Amsterdam e.a. 1992, 53-82.

87 See G. Bunnens, Tell Ahmar II. A New Luwian Stele and the Cult of the StormGod at Til Barsib-Masuwari, Leuven 2006, 78-83 and idem, AOAT 318, 58-65. Cf. already the brief remarks in Wettergottgestalten, 620f. with fn. 5011. 
regions and periods in which the concrete reading of the logogram for the storm-god in the texts is difficult, the specific naming of pictorial representations of the god is problematic too, even if, as in the glyptic of the Old Assyrian period or of Late Bronze Age Emar, the various iconographic traditions can be clearly differentiated. ${ }^{88}$

One of the typical manners of depicting the storm-god shows him with a weapon (or the lightning symbol) raised to strike, a gesture which is attested with other warlike gods as well. In 2nd mill. Syria, Anatolia and Upper Mesopotamia the storm-god often stands on mountains (gods) or, especially in the 1st mill., on a bull. A few Old Syrian seals show the storm-god as killer of a snake. These depictions certainly refer to the motif of the storm-god as victor over monsters living in the sea, which is attested within the framework of the myths about the storm-god defeating the sea. ${ }^{89}$ The Syrian storm-god is depicted on seals - but particularly prominently on the famous Balu-stele from Ugarit - with a downward-pointing lance, the upper shaft of which ends in plant-like lines. This vegetal shaft-end has been interpreted as a symbol for the vegetationfurthering effect of the storm-god, as a 'tree-of-life', as 'tree-weapon' 90 or as stylised lightning symbol ('lightning-tree' with reference to 's $\mathrm{brq}$ in CAT 1.101 obv. 4). In my view the plant-like shaft-end may rather be a pictorial representation of the rolling thunder, as it is frequently attested in Syrian glyptic art before the mouth of the storm-god, albeit in horizontal orientation. ${ }^{91}$

${ }^{8}$ Cf. E.A. Braun-Holzinger, WdO 33 (2003) 265f. with respect to the stormgod iconography of the Emar seals: "Ob die Siegelbesitzer wirklich diese drei Bildtypen unterschiedlich benannten, ist fraglich; so wie der meist ${ }^{\mathrm{d}} \mathrm{IŠKUR}$ geschriebene Namen des Wettergottes unterschiedlich gelesen wurde, konnte auch der Bildtyp des waffenschwingenden Gottes mit Blitz sicher unterschiedlich 'gelesen' werden”.

${ }^{89}$ See the references given in Wettergottgestalten, 227f. with fn. 1575, and cf. now also W.G. Lambert, "Leviathan in Ancient Art", in: Shlomo, Studies Sh. Moussaieff, ed. R. Deutsch, Tel Aviv-Jaffa 2003, 147-154, who proposes to identify the snake depicted on the seals with Leviathan of the Ugaritic and Biblical texts.

${ }^{90}$ For this interpretation see now also P. Lapinkivi, The Sumerian Sacred Marriage in the Light of Comparative Evidence, SAAS 15, Helsinki 2004, 265-269 without any new supportive evidence for the argument.

91 Thus Wettergottgestalten, 227 fn. 1575; for the interpretation of the plant-like motif in front of the storm-god's mouth as a symbol for thunder see E. WilliamsForte's study "Symbols of Rain, Lightning, and Thunder in the Art of Anatolia and Syria", in: Aspects of Art and Iconography: Anatolia and Its Neighbours. Studies $\mathcal{N}$. Özgüç, ed. M.J. Mellink e.a., Ankara 1993, 185-190. But especially in view of CAT 1.101 obv. 4 where within a description of Ba'lu the image of the god's lightning in the sky is likened to a tree bearing multiple branches ( ${ }^{s} s$ brq "tree of lightning") an interpretation as stylised lightning cannot be ruled out either. 


\section{Appendix: Selected Additions and Corrections to Schwemer,} Wettergottgestalten

Excluded from the following list have been all additions and corrections which form part of the preceding article. The following reviews of Wettergottgestalten have been published so far: M. Dietrich, UF 33 (2001) 657-677, H. Klengel, OLZ 97 (2002) 752-754, G.A. Klingbeil, DavarLogos $1 / 2$ (2002) 189-202, S. Noegel, fHS 4 (200203), D. Fleming, ZA 93 (2003) 282-288, L. Feliu, AuOr 21 (2003) 295-300, M. Köckert, ZAW 115 (2003) 317, E. Cancik-Kirschbaum, WdO 34 (2004) 199-202, R.D. Biggs, JNES 63 (2004) 212-214, J.-G. Heintz, RHR 84 (2004) 208-210, D. Charpin, RA 99 (2005) 185-186.

p. 12 with fn. 56: On LAK 376 and 377 see now also M. Krebernik, "Die Texte aus Fāra und Tell Abū Șalābīhn", in: J. Bauer-R.K. Englund-M. Krebernik, Mesopotamien. Späturuk-Zeit und Frühdynastische Zeit, Fribourg 1998, OBO 160/1, 277.

p. 16: For Old Babylonian manuscripts of An-Anum (or an Old Babylonian form of An-Anum) see VS 24, 16 and 17; cf. also J. van Dijk, "Inanna raubt den 'grossen Himmel': Ein Mythos", in: tikip santakki mala bašmu. ... Fs. R. Borger, ed. S.M. Maul, CM 10, Groningen 1998, 9-10 with fn. 3 on SLT 121 and UM 29-15-229.

p. 17 fn. 88: For Nindagar cf. now also G. Selz, "Babilismus' und die Gottheit 'Nindagar", in: Ex Mesopotamia et Syria Lux. Fs. M. Dietrich, AOAT 281, Münster 2002, 647-684, esp. 676 (interpretation of An-Anum I 326 misleading, however).

p. 39 with fn. 204 and passim: Following M. Streck (AOAT $271 / 1,240 f f ., 187 f f$.$) spellings like z i$-im-ri-E-id-da are interpreted as Zimriyidda (zi-im-ri-ji-id-da) in Wettergottgestalten. It should be noted, however, that names like $i a-a q-q u \dot{u}-u b-\mathrm{E}-d a$ and $i a-a b-l u-u t-\mathrm{E}-d a$ (see Wettergottgestalten, 44) suggest that a variant Edda (or $Y a / i d d a$ ?) developed also outside the phonetic context $i(h) a$ resp. iya $(>$ iy $i>e / i)$. The usage of the sign E needs further study. D. Charpin (and others) still prefer to assume a contraction $i+a>\hat{e}$ (Zimrêddu etc.), see most recently $R A 98$ (2004) 156 ad x 9.

p. 44: Add possibly the PN Bu-ul-li-tá-di (Labarna letter rev. 25, see M. Salvini, The Habiru Prism of King Tunip-tešsup of Tikunani, DA 3, Roma 1996, pp. 107ff.).

p. 56 fn. 299: J. Quack draws my attention to another late attestation of the name Adad overlooked by me at the time: Proclus, 
In Parmenidem VII p. 58.30-60.9: "the demiurgic intellect of the world, which they call 'Adad, worthy of all praise"” (see Proclus' Commentary on Plato's Parmenides, ed. G.R. Morrow-J.M. Dillon, Princeton 1987, 594, cf. also H.D. Saffrey, Recherches sur le néoplatonisme après Plotin, Paris 1990, 77f.).

p. 57: Add the following syllabic spelling of Adad (Addu) in Assyrian SB manuscripts: ${ }^{\mathrm{d}} a d-d i$ (unpubl. 81-2-4, 311 l. col. 9'), ${ }^{\mathrm{d}} a d-d u$ (S.M. Maul, MDOG 133 [2001] 19: VAT 10916 obv. 14', now also in: A.R. George, The Babylonian Gilgamesh Epic, Oxford 2003, vol. 2, pl. 31), ${ }^{\mathrm{d}} a-d a-a\left(K A R 237\right.$ obv. 20), ${ }^{\mathrm{d}} a d-d e-e-a k a-\operatorname{sir}$ erpēti(Dungu.Mě̌) (Ass. Ph. 4198d = Ass. 13956fs = A 2731 obv? 1, excavation and Istanbul museum number courtesy S.M. Maul).

p. 84: dad-gi is attested as (corrupt?) variant of $\mathrm{d}^{\mathrm{ad}-g i_{4}-g i_{4}}$ in $C T$ 24, 32: 97b (An-Anum III 167). The latter is usually understood as divine counselor and ${ }^{\mathrm{a} a d-g i} i_{4}$-mah would then be the supreme counsellor (see B. Alster, "Incantation to Utu", ASf 13 [1991] 52: 95 and the pertinent note ibid., 84, cf. also PSD A III 18-19). Whether the god Adgi qualified as MIN (= $\left.{ }^{\mathrm{d}} \mathrm{IŠKUR}\right) s u-u h^{\mathrm{ki}}$ is the same Adgi remains questionable. Note that Sum. ad-gi -gi $_{4}$ is also translated as rigma apālu "to resonate" (see OBGT XVII 7, see MSL 4, 127) which might provide a more fitting etymology for a stormgod called Adgi.

p. 86: The spelling ${ }^{\mathrm{d}} b a^{-} u-u-l u$ for expected $* b a-a^{3}-l u$ (Ba'lu) was explained as a 'phonetic' rendering of West-Semitic '. W.R. Mayer suggests that the form could be explained as a qattul-form which is used for affectionate names in Aramaic, Hebrew and Arabic (see F. Praetorius, "Über einige Arten hebräischer Eigennamen", ZDMG 57 [1903] 773-776 [with further literature], M. Noth, Die israelitischen Personennamen, Stuttgart 1928, 38): "Entsprechend könnte man vorschlagen, $b a^{\text {« }} \bar{u} l\left(b a^{-} u-\hat{u}-l u\right)$ für so einen Kosenamen des Gottes Bal zu halten" (letter, 8th May 2007). While this interpretation provides an elegant explanation of the aberrant spelling, it seems unlikely that a list like K 2100 would include a rare by-form of the god's name rather than its normal form.

p. 103: On $p a_{4}-\check{s} i \check{s}$ see now Th. Krispijn, "pa $a_{4}$-šeš 'Ältester" ", in: Von Sumer nach Ebla und zurück. Fs. G. Pettinato, ed. H. Waetzoldt, Heidelberg 2004, 105-112.

p. 107: On ki:lam ${ }_{x}$ see now also M.G. Biga, "Marginal Considerations on the Hittite KI.LAM-Festival", in: Anatolia antica. Studi F. Imparati, ed. St. de Martino e.a., Eothen 11, Firenze 2002, vol. I, 101-108.

p. 109 fn. 752: S. 105f. (not "150f."). 
p. 111 fn. 772: 75.2507 (not “75.207”).

p. 134: For kt j/k 97 cf. now also K. Hecker, TUAT. Ergänzungslieferung, ed. O. Kaiser, Gütersloh 2001, 58-60 and J.G. Dercksen, JEOL 39 (2006) 107-29.

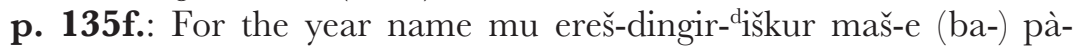
da see also D.R. Frayne, RIME 3/2, p. 18 (with the additional reference L 39705). He assigns the date to Urnamma and argues that it probably refers to the temple in Karkar (but cf. for an erešdingir of Iškur in Lagaš Wettergottgestalten, 140).

p. 144 and passim: On the element ur in names like Ur-Iškur see A. Cavigneaux-F.N.H. Al-Rawi, Gilgameš et la mort. Textes de Tell Haddad VI, CM 19, Groningen 2000, 48-52.

p. 168: For Iškur as Enki's twin cf. also M.W. Green, Eridu in Sumerian Literature, Diss. Chicago 1975, 91.

p. 175 fn. 1236: Add a reference to S.M. Maul, "Eine neubabylonische Kultordnung für den Klagesänger (kalû)", in: Kulturgeschichten. Fs. V. Haas, ed. Th. Richter e.a., Saarbrücken 2001, 255-265 $\left(\mathrm{gu}_{4}{ }^{-}\right.$ mah pa-è-a).

p. 176 fn. 1238: Add Å.W. Sjöberg, "Miscellaneous Sumerian Texts, II", FCS 29 (1977) 20 rev. I 2.

p. 176 fn. 1239: Add CTN 4, 107 rev. 6; cf. also A. Cavigneaux, "Fragments littéraires susien", in: Literatur, Politik und Recht in Mesopotamien. Fs. C. Wilcke, ed. W. Sallaberger e.a., 61, Sb 12630: 6 (Adad provides an unnamed monster with its thundering roar). In HS 1885 obv. 6'-7' read: ${ }^{6}[a]-{ }^{\ulcorner} \breve{s} a^{\top}-a s-s i-m a k i-i{ }^{\text {d IŠKUR } u-p a-a} a-\check{s} a-$ kan ${ }^{7}$ ' $a$-na um-ma-an sa-am-su-di-ta-na $\left\ulcorner u t^{\urcorner}-t a-a\right.$ u $u_{4}-m a$ "I roar and like Adad I create a cloud darkening the day for Samsuditana's army" (coll., M. Krebernik had the kindness to give me his transliteration of the whole fragment).

p. 181 fn. 1263: $A B R T$ 1, 60: 16-17 reads according to W.R. Mayer's collation (letter, 29th June 2004): ${ }^{16} i$-mur-šu-ma d Adad(IŠKUR)

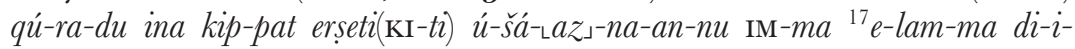

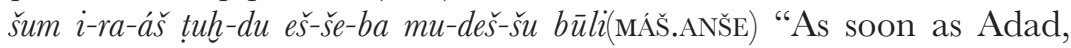
the hero, has seen it, he makes rain fall upon the entire earth, the spring growth shoots up rejoicing, abundance flourishes, which provides plenty of livestock."

p. 190: Ur-Ninurta's hymn to Iškur (VS 17, 40, see ETCSL 2.5.5.6, and correct my transliteration in obv. 1 and 8 accordingly) is entered in the Old Babylonian catalogue UET 6/2, 196, see A. Shaffer, "A New Look at Some Old Catalogues", in: Wisdom, Gods and Literature. Studies W.G. Lambert, ed. A.R. George-I.L. Finkel, Winona Lake 2000, 432f. 
p. 201 fn. 1381: Add MDP 27, 286 II 7: dwe-e[r] (god-list, Wēr after Huwawa).

p. 207 fn. 1437: Delete the "Korrekturnachtrag" (read werru, not Wēr).

p. 208: For Bēr cf. also the Neo-Assyrian 'god-list' KAV 72 obv. 10' and 11' (deities of Kār-Tukultī-Ninurta?). For the possibility of Tell Afis = Hatarikka ("Hazrak") see E. Lipiński, The Aramaeans. Their Ancient History Culture, Religion, OLA 100, Leuven 2000, 255-257.

p. 212: For A. 1314 obv. 16-18 cf. now M. KrebernikM. Streck, "šumman lā qabi àt ana balāțim-Wärest du nicht zum Leben berufen. ... Der Irrealis im Altbabylonischen", in: Sachverhalt und Zeitbezug. Fs. A. Denz, ed. R. Bartelmus-N. Nebes, Wiesbaden 2001, 60 .

p. 238: For the legend on the cylinder seal kt e/t 180 see M.T. Larsen, The Old-Assyrian City-State and its Colonies, Mesopotamia 4, Copenhagen 1976, 115 fn. 23 (reading SANGA! $\check{s u}$ d!IŠKUR in 1. 4).

p. 245 fn. 1717: For hamru "wine" in Emar cf. also A. Tsukimoto, "A Medical Text from the Middle Euphrates Region", in: Priests and Officials in the Ancient Near East, ed. K. Watanabe, Heidelberg 1999, 192: 7 .

p. 254: VBoT 13: 9': $\operatorname{read} I \check{S}-\llcorner T U\lrcorner\left(\right.$ not $I \check{S}-\left\llcorner T U_{\lrcorner}\right)$.

p. 255 fn. 1776: For DINGIR ha-ma-ri see J.G. Westenholz, "Emarthe City and its God", in: Languages and Cultures in Contact. Proceedings of the 42th RAI (OLA 96), ed. K. van Lerberghe - G. Voet, Leuven 1999, 145-67.

p. 302: For $A R M$ 7, 219 see now M. Guichard, $A R M$ 31, 133 (cf. also $132=A R M 7,119)$.

p. 302 fn. 2224: Add te-ě́šru-ba-aš ku-mu-ni in VS 17, 6 obv. 12.

p. 321 fn. 2474: The year date in De Meyer, Tell ed-Dēr 2, 165 n 27 rev. 11f. should probably be read: MU $\check{s} a u \breve{s}(\mathrm{e})-\check{s} i \check{s} a$ É ${ }^{\mathrm{d}} \mathrm{IŠKUR}$ A-mi-sú-um $i-d u$ "Year in which A. laid the foundations of the Adad temple" (I owe this reading to F. van Koppen). This provides us with the building date of the Old Babylonian Adad temple of Sippar.

p. 393f.: D. Charpin, FAOS 121 (2001) 686 argues that the oath by "Adad, their god" in an Old Babylonian document from Susa shows that Adad was the city-god of the family's Babylonian home-town.

p. 411 fn. 3446: S. 137 mit Anm. 953 (not "S. 136 mit Anm. 946").

p. 413ff.: On Haniš cf. now also M. Stol, "Das Heiligtum einer Familie", in: Literatur, Politik und Recht in Mesopotamien. Fs. C. Wilcke, ed. W. Sallaberger e.a., 293-300. 
p. 426 fn. 3528: ša é-sag-gíl may well be part of the original inscription; the seal then would have belonged to the Adad worshipped in Babylon's main sanctuary (cf. p. 638f.).

p. 446 fn. 3709: For Ea-šarru cf. also H.D. Galter, Der Gott Ea/Enki in der akkadischen Überlieferung, Graz 1983, 14-16, and S.M. Maul, "Neue Textvertreter der elften Tafel des Gilgamesch-Epos", MDOG 133 (2001) 46f.

p. 447, 1.22: Despite the copy the traditional reading na-aš (not MUŠEN-ǎ̌ is probably preferable.

p. 448, 1.31: For this line see now H.A. Hoffner, Die Sprache 43 (2002-3) 80, 84f.

p. 457 fn. 3774: $K U B 36,7 \mathrm{a}+17,7+($ instead of "KUB XXXVI $7 \mathrm{a}+||$ VII 7+).

p. 458 fn. 3779: In light of the cult inventory $K U B 38,12$, I would still argue that the cities of Kumme (Kummiya) and Kumma (in the region of Hurma?) should be kept separate. It must be admitted, however, that the sequence of deities in $K U B$ 45, 77: 10' $=$ ChS 1/9, 104 (storm-god of Kumma, sun-goddess of Arinna, Hēbat) suggests that Kumma is also used as a by-form of Kumme (Kummiya). Otherwise the evidence is inconclusive: The storm-god of Kumma is named beside the storm-god of Halab in the oracle-text IBoT 1, 33 (obv. 42) and might be mentioned in IBoT 2, 70 rev. 1', a fragmentary list of storm-gods, before the storm-god of Halab and the storm-god of invocation (halziyawaš), who belongs to the circle of the Aleppine storm-god. The storm-god of Kumma figures prominently in $K U B$ 3, 87, an Akkadian fragment that appears to be part of a letter, probably sent by an important prince or official in the region of Mittani, maybe in Alze, to Suppiluliuma. The text deals with oracle messages of the storm-gods of Iptalaim (sic?) and Kumma within the context of Šuppiluliuma's Syrian campaign. The text mentions Antaratli, who is well known from the historical introduction of the Šattiwaza-treaty. This suggests that the letter was written sometime shortly before, during or after Šuppiluliuma's one-year campaign, when Šuppiluliuma installed Antaratli as king of Alze. The message of the storm-god of Kumma reminds one of the oracles of the stormgod of Halab quoted in the famous letters of Zimrī-Līm's Aleppocorrespondence. I offer a tentative transliteration and translation of the fragment (cf. also A. Hagenbuchner, Die Korrespondenz der Hethiter, THeth 16, Heidelberg 1989, II 459f. text 349; for a photograph see S. Košak, Konkordanz der hethitischen Keilschrifttafeln, Online-Datenbank, Version 1.1: http://www.hethport.uni-wuerzburg.de/hetkonk/): 


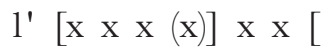

2' [DUMU.KIN-r] $a(?) \check{s} u-u[p-r a-a \check{s}-\check{s} u-m i(?)$

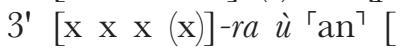

4' [x x $i-d] i(?)-i n-\check{s} u$ ̀े $\mathrm{x}$ [

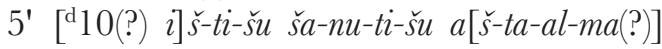

6' $[i q-t a-b i(?)]{ }^{\text {Iš }}$-up-pi-lu-li-u-ma ÌR $k[\dot{e}-n u]$

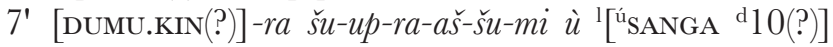

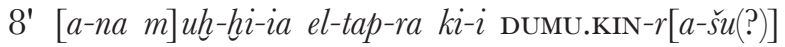

9' [ik-šu]-du ù I an-tar-at-li a-na mu-uh-hi-[ia el-tap-ra]

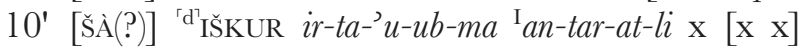

11' $[i-n] a-a n-n a{ }^{\mathrm{d}} 10{ }^{\mathrm{uru}} k u m-m a$ i-na $\check{s} a-l u-u[l-t i]$

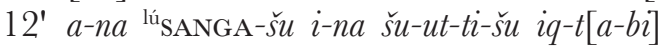

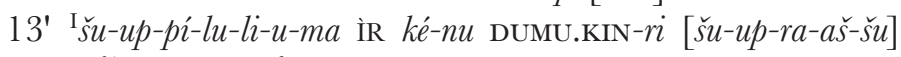

$14^{\prime} \dot{u}{ }^{\text {lú SANGA } \check{s} a}{ }^{\mathrm{d}} 10{ }^{\text {uru }} i p-t a-l a-i[m(.)$.

15' a-na muh-hri-ia il-tap-ra ki-i DUMU.[KIN-šu(?)]

16' i-na KUR uru al-zi-ia ik-šu-du [ù d $10(?)]$

17' [uru ip]-ta-la-im a-na muh-hi-ia DUMU. [KIN il-tap-ra(?)]

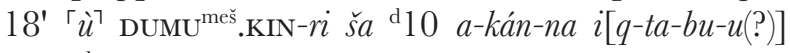

19' ['] ${ }^{\ulcorner} 10^{\urcorner}(?)$ uru kum-ma te ${ }_{4}-e-m a$ a-kán-na [iš-ta-pa-ar(?)]

20' $[a-n] a(?){ }^{\text {I }} \check{s} u-u p-p i-l u-l i-u-m a$ İR ké-n[u aq-ta-bi(?)]

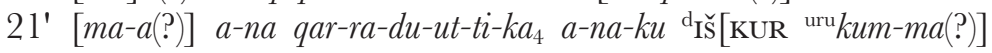

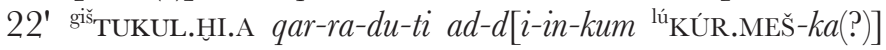

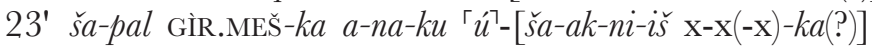

24' a-na-ku-me ̀̀ ${ }^{\mathrm{d}} 10$ uru kum-m[a

25' [LU]GAL(?)-ia el-li-ku x [

$26^{\prime}[\mathrm{x}(\mathrm{x})] \mathrm{x}$ lúkÚR [

$27^{\prime}[\mathrm{x} \quad \mathrm{x} \quad \mathrm{x}]\left\ulcorner^{\ulcorner} a^{\urcorner}-n a\right.$ DUMU. [KIN

$[\ldots] \ldots$. . " [. . ] se[nd a messeng $]$ er $[$ to him $]$ ! [...] and $[\ldots$ gi $]$ ve him!" And... [...]. [I asked the storm-god o]nce (and) a second time, [and he said:] "Šuppiluliuma is a lo[yal] servant, send [a messenger] to him!" And the p[riest of the storm-god] sent (a message) [t]o me. When [his] messenger [arri]ved, Antaratli too [sent (a message)] to [me]. The storm-god['s heart] was angry so that Antaratli [was...]. [N] ow the storm-god of Kumma has spo[ken] for a third time to his priest in his dream (saying): "Šuppiluliuma is a loyal servant, [send] messengers [to him]!" And the priest of the storm-god of Iptalai[m (. . .)] sent (a message) to me. When [his] mess[enger] arrived in the land of Alziya, [the storm-god of Ip]talaim (possibly a mistake for 
Kumma?) too [sent] a messe[nger] to me. And the messengers of the storm-god s[poke] thus: [the st]orm-god of Kumma [has sent] a message (saying) thus:

"[T] Š Suppiluliuma, the loy[al] servant, [I have said]: For your valor, I, the storm-[god of Kumma], ga[ve you] weapons of valor. [Your enemies] I [made bow down] at your feet. [Your...] I am!"” And the storm-god of Kumm[a ...

Unfortunately the fragmentary text contains no information on the location of Kumma. The storm-god of Iptalaim is unknown otherwise; the mere fact that the storm-god of Kumma is referred as the god who gave Šppiluliuma his weapons can hardly prove that it is the famous Teššub of Kumme whose oracle is consulted. If the author of our letter was in the region of Alze at the time and if Kumma is to be sought not too far from Hurma, it could well be the storm-god of South-Anatolian Kumma who is referred to here, not his famous counterpart residing far away on the Eastern Habur.

p. 479: For $K U B$ 7, 60 // see now G. Del Monte, "The Hittite Herem", Babel und Bibel 2 (2005) 21-45.

p. 459 fn. 4054: Note that $K B o$ 21, 26 and 34, 203 are listed as indirect joins by S. Košak and classified as "jh.".

p. 499 fn. 4085: For ${ }^{\mathrm{d}} 10$ Ti-bi cf. now also V. Haas, OrNS 67 (1998) 138.

p. 509: For the reading of the personal names in the Tell Ta'anakh texts see the new edition of the texts in W. Horowitz-T. Oshima, Cuneiform in Canaan. Cuneiform Sources from the Land of Israel in Ancient Times, Jerusalem 2006, 127ff.

p. 515 fn. 4185: For RS 17.116 obv. 2'f. see now S. Lackenbacher, Textes akkadiens d'Ugarit, LAPO 20, Paris 2002, 120 fn. 365.

p. 517: "kinnāru-Leier" (not "kinnāru-Laute").

p. 554: For RPAE 6/3, 42 see now also M.R. Adamthwaite, Late Hittite Emar, Leuven 2001, 262ff.

p. 555: In RPAE 6/3, 202 obv. 13 read probably $\check{s} a$ É Id IŠKuR-ba$r i$ (I owe this reading to An de Vos, for the name Adad-bārû see Wettergottgestalten, 587, 653, fn. 4743).

p. 556: Note that Msk 731042 and 74286a actually join (see W. Sallaberger, ZA 86 [1996] 140-147).

p. 570: For the reading of the logogram IR see now J.D. Hawkins, in: S. Herbordt, Die Prinzen- und Beamtensiegel der hethitischen Großreichszeit auf Tonbullen aus dem Nişantepe-Archiv in Hattusa, Mainz 2005, $296 \mathrm{f}$. 
p. 573 and passim: Read zêrāšu (not "zêršu").

p. 575f.: For ICC 73 cf. also B.R. Foster, Before the Muses, ${ }^{32005,} 292$.

p. 580: For the two Kūbu's of the Anu-Adad temple see now also MARV 6, 35 rev. 38f.

p. 601f.: For rites in Assur's Anu-Adad-temple in the Neo-Assyrian period cf. now also S.M. Maul, "Die Frühjahrsfeierlichkeiten in Aššur", in: Wisdom, Gods and Literature. Studies W.G. Lambert, ed. A.R. George-I.L. Finkel, Winona Lake 2000, 407, 410, 420.

p. 603: For qersu cf. now D. Fleming's comment in ZA 93 (2003) 288.

p. 665f. fn. 5520: For VAT 10018 // 14226 see now M.J. Geller, "Akkadian Evil Eye Incantations from Assur", ZA 94 (2004) 52-58.

p. 668: Translation 1. 37: "mirsu-Speise mit Sirup und Butterschmalz".

p. 683: K 3794 obv. 5: For a better translation of the phrase ina amātīya... ina tamīt akarrabu kittu libši see now W.R. Mayer, "Das Gebet des Eingeweideschauers an Ninurta", OrNS 74 (2005) 55f.

p. 683 fn. 5612: L. 6 ' read GUB-su (tušzāssu), 9': NINDA.ì.DÉ.A. 